Man and Nature

L'homme et la nature

\title{
Planning Space for the Masses in France 1789-1799
}

\section{James A. Leith}

Volume 6, 1987

URI : https://id.erudit.org/iderudit/1011919ar

DOI : https://doi.org/10.7202/1011919ar

Aller au sommaire du numéro

Éditeur(s)

Canadian Society for Eighteenth-Century Studies / Société canadienne d'étude du dix-huitième siècle

ISSN

0824-3298 (imprimé)

1927-8810 (numérique)

Découvrir la revue

Citer cet article

Leith, J. A. (1987). Planning Space for the Masses in France 1789-1799. Man and Nature / L'homme et la nature, 6, 225-267. https://doi.org/10.7202/1011919ar

Copyright (c) Canadian Society for Eighteenth-Century Studies / Sociéte canadienne d'étude du dix-huitième siècle, 1987
Ce document est protégé par la loi sur le droit d'auteur. L'utilisation des services d’Érudit (y compris la reproduction) est assujettie à sa politique d'utilisation que vous pouvez consulter en ligne.

https://apropos.erudit.org/fr/usagers/politique-dutilisation/ 


\section{PLANNING SPACE FOR THE MASSES IN FRANCE 1789-1799}

Since this is an after-dinner talk rather than a formal lecture, I am going to be more personal (although in case anyone wants to publish my talk, I have put in footnotes). I have been working for five or six years on a work entitled Space and Revolution: Projects for Monuments, Squares and Public Buildings in France 1789-1789. How I came to be engaged in such a project may interest you.

I first became acutely aware of the social influence of architecture as a member of a committee planning a new humanities building for Queen's University. The committee divided into those who favoured a vertical approach over a horizontal one. Lest this be misunderstood, I hasten to explain that the vertical school wanted some of each department on each floor so that the departments would be mixed. They would share one large lounge on the top floor. The horizontal faction wanted each department to have all of its offices on one or two floors so that colleagues in one discipline could communicate easily. Each department would have a lounge and a departmental office just down the hall. This horizontal school won out, with the result that members of departments in the same building rarely meet except on the elevator and use their own lounges. This experience convinced me of the way architecture can affect our daily lives.

With my interest sparked, I delved into the literature on how various regimes have tried to design architecture to serve their political goals, especially regimes which have believed in social engineering. 
I was intrigued by Anatole Kopp's Ville et Révolution which analysed how the Bolsheviks in the 'twenties sought to create apartment buildings, workers' clubs, and cultural centres which would encourage communal living. ${ }^{1}$ Also I learned from the works of Barbara Lane ${ }^{2}$ and Robert Taylor ${ }^{3}$ how the Nazis planned 'Hitlerplatzen', imposing monuments, grandiose public buildings, youth centres, and rally grounds to help shape citizens for the Third Reich.

There was no work on the French Revolution comparable to those of Kopp, Lane, and Taylor, although Jean Starobinski had touched on the architecture of the Enlightenment and Revolution as symbolizing a new era. ${ }^{4} \mathrm{I}$ had, however, noticed numerous projects after 1789 . As I probed deeper, I came upon hundreds of plans for monuments, squares, public buildings, and arenas. The revolutionaries realized that architecture could serve a political purpose in three basic ways. First, imposing monuments, charged with inscriptions and symbols, could convey messages to the citizenry. Second, projects for buildings with a social purpose -- public baths, market places, commercial facilities, museums, hospitals -- could convince the citizenry that the government was striving to serve their interests. Third, boulevards could be planned and spaces created which would facilitate processions through the streets and mass rallies. It is one aspect of the third objective which I would like to analyse briefly.

The traditional meeting places were not suited for mass assemblies. Most churches were too cramped and their cruciform shape often impeded unity. The theatres were not only too small, but hierarchical and compartmentalized. There was, however, one architectural form which the revolutionaries considered ideal: the amphitheatre. Interest in amphitheatres had grown during the previous half-century because royal festivities surrounding marriages, births, and Peace treaties were already developing into something akin to national celebrations. The designs done by students competing for prizes in the Académie Royale d'Architecture sometimes included vast amphitheatres, hippodromes, or circuses. For instance, in 1781 Jean-Nicolas Sobre won a prize for a design for buildings to accommodate a festival celebrating peace, in 1783 Antoine-Laurent-Thomas Vaudoyer won a prize for a menagerie of a prince with a large amphitheatre in the centre, and in 1787 Réverchon won a prize for an immense hippodrome ${ }^{5}$ (Figs. 1, 2).

In planning space which could influence human behaviour, the revolutionaries were especially interested in creating enclosures where people could congregate for civic rituals. To understand what they were trying to do, we must keep in mind their notion of politics, which was quite different from ours. They rejected the idea of politics as a con- 
test between coalitions or parties representing different interests. They aspired to create a single national will. This aspiration has been attributed to the concept of the general will elaborated by Rousseau in his Contrat Social, but it probably owed more to an ancient concept of sovereignty. Under the Old Regime the king had theoretically been sovereign, and presumably he had been motivated by a single will. When the revolutionaries declared that the nation was sovereign they simply turned the old system up-side-down. The nation, like the king, should have a single will. To create such a will the revolutionaries wanted spaces, either outdoor or indoor, where the people would merge together.

Notice the word 'create'. Although revolutionary governments claimed to speak in the name of the people, they were never satisfied with the people as they were. The existing people were captive to old ways of thinking, often divided, and frequently unruly. The ideal people would have to be created. The revolutionaries were consequently dissatisfied with the places where the people gathered spontaneously such as the Pont Neuf, the Place de Grève, or the Palais Royal. In such gathering places the people were uncontrolled. The revolutionary leaders wanted enceintes, enclosures where the people could be controlled and reeducated. Revolutionary festivals were instruments of social control and indoctrination.

Eighteenth-century scholars and architects emphasized the political and psychological advantages of amphitheatres. In 1781 the Abbé Brotier read a series of papers to the Académie des Inscriptions on the political use which the Romans had made of such structures. ${ }^{6}$ It was the circus, he argued, not the theatre, which was at the heart of Roman life. It was at the circus that the Romans rallied in times of adversity, and it was there that they celebrated their victories. Citing the arguments of the learned Abbé, the avant-garde architect Etienne-Louis Boullée pointed out that the French had no place comparable to the Roman Coliseum in which to hold national celebrations, which were held principally in Paris. ${ }^{7}$ The square in front of the city hall could not accommodate more than a fraction of the populace of Paris. What was needed was a huge amphitheatre where three hundred thousand people could unite. The effect of such a living mass, where no one could escape the view of the multitude, would be unique. Boullée designed such an amphitheatre for the as yet undeveloped area called ' 1 'Etoile' at the end of the Champs-Elysées (Fig. 3). It was modelled on the Coliseum in Rome, but the architect claimed that he had improved the style.

When the Constitutent Assembly decided to hold a great celebra- 
tion on July 14, 1790 to commemorate the storming of the Bastille and the achievements of the first year of the Revolution there was still no adequate space for such a rally. In recent months local and regional 'federations' had taken place in which troops of the line and National Guards swore to defend the Revolution. Now the plan was to bring troops from all over France for a great national Festival of Federation in the capital in which the King himself would participate. After considering several sites, the planners appointed by the Assembly chose the Champ de Mars, the parade ground in front of the École Militaire on the left bank of the Seine. ${ }^{8}$ There the populace of Paris laboured enthusiastically to create a vast amphitheatre capable of holding three hundred thousand. More could watch from the hills of Passy and Chaillot on the right bank.

The temporary architectural scheme was an amalgam of proposals by several architects -- Georges-François Blondel, Jacques Cellerier, and Bernard Poyet. A temporary bridge on pontoons led across the Seine to the festival grounds (Fig. 4). A vast enclosure was created by a triumphal arch which served as the entrance, the sloped sides which created a giant but shallow bowl, and a pavilion at the south end to accommodate the King and the deputies of the Constituent Assembly. In the centre, raised up on a perron, was an altar decorated with revolutionary reliefs and inscriptions where mass was celebrated and at which an oath to the new order was taken in turn by the troops, the King, and the citizens. This enclosure could be likened to a huge outdoor cathedral in which the sky formed a vast cupola overhead, but it differed from a cathedral in several ways -- it was not cruciform, the altar was only half-Christian, and it was not oriented toward the Holy Land. For the revolutionaires, if there was any sacred centre, it was now Paris and France.

The success of the Festival of Federation confirmed the belief of revolutionaries that the amphitheatre was the ideal space for mass rallies. Thereafter there were recurrent proposals for a permanent amphitheatre. Wood covered with canvas painted to look like marble could not convey the grandeur of the Revolution. One of the most interesting proposals was part of the scheme put forward by the politican Armand-Guy Kersaint in his Essai sur les monuments publics. ${ }^{9}$ Kersaint, and his architect associates Jacques-Guillaume Le Grand and Jacques Molinos, proposed conversion of the uncompleted church of the Madeleine into a National Assembly, completion of the Louvre to contain both a national art gallery and a national library, erection of a 'prytaneum' in every neighbourhood on which the laws could be posted, and a huge stone amphitheatre on the Champ de Mars (Fig. 5). 
Kersaint even anticipated the ruin-value theory of architecture enunciated by Speer in the twentieth century in regard to the Nazi rally grounds in Nuremburg. Since the amphitheatre would be in granite and marble, even if France declined in the future, the ruins would attest to her grandeur and that of her Revolution.

Architects in the provinces shared the aspiration to create enclosures for revolutionary rituals. In Bordeaux the local Festival of Federation had taken place in the Jardin Public at the edge of the city. The local engineer of civil buildings, Louis Combes, envisaged a permanent 'cirque national' on ecclesiastical property recently nationalized by the revolutionary government. ${ }^{11}$ The plan is a good example of eighteenthcentury planning: it features radiating places, new avenues, a hospital, public baths (with the sexes carefully segregated), and verdant areas, as well as the circus (Fig. 6). This plan seems to have been done under the constitutional monarchy since it still displays royalist names.

Early in the republic Combes and other architects proposed to create a vast amphitheatre in the Jardin Public capable of holding up to thirty-five thousand people. ${ }^{12}$ In this immense enclosure festivals lasting several days could be staged. Combes believed that, if skilfully managed, such festivals would remove the divisions among the people and their sense of individual problems. Two other architects, Dufort and Bonfin, also emphasized the psychological advantages of such rallies for the regime:

Il faut à notre nouvelle vie politique, à nos nouvelles moeurs, à notre nouvelle ambition, un théâtre immense où les acteurs et les spectateurs s'excitent entr'eux, où la présence et les applaudissements des uns redoublent l'ardeur des autres, et où le tableau imposant d'une grande ville rassemblée, aille remuer l'âme de l'être le plus froid. ${ }^{13}$

As the Revolution moved onward to the Republic and then to the Terror, no permanent amphitheatre was constructed. The revolutionaries had to make do with monasteries or churches for local meetings and clubs, and ephemeral architecture for larger festivals, but the ideal of the amphitheatre persisted. Very revealing was the transformation, on orders of the Committee of Public Safety, of the Théatre Français, now known as the Odéon, into a Théâtre du Peuple. ${ }^{14}$ One of the original architects, Charles de Wailly, was directed to oversee the conversion. The auditorium inside was redone in tricolour decor and the foyer decorated with allegorical figures. The surviving drawings also revealed that at every level stalls were removed to make the theatre as much as possible into an amphitheatre where the citizens would merge 
and share emotions (Fig. 7). ${ }^{15}$ On the plan the old arrangement appears on the left, the new arrangement on the right.

The alterations inside were completed. ${ }^{16}$ It is not clear whether the plans for the semicircular square in front of the theatre were realized, but they too offer a fascinating insight into revolutionary objectives. The semicircle had been designed to suggest the shape of the auditorium inside. If we complete the circle, it transects the stage (Fig. 8). ${ }^{17}$ Now de Wailly redesigned the place so that it would not only suggest the theatre inside, but would become a covered outdoor amphitheatre with the original theatre as a backdrop. The square was to be enclosed by a colonnade punctuated by arches over the entrances from the adjacent streets (Fig. 9). Benches were to be created around the edge. The whole space was then to be covered with canvas to protect the audience from the elements (Fig. 10). The poles supporting this cover were to be decorated with tricolour banners, Phrygian bonnets, and Levels of Equality.

The Revolutionary Government was not content with such renovated facilities. In the spring the Committee of Public Safety launched an ambitious cultural program embracing all the media - newspapers, songs, plays, painting, sculpture, and architecture. ${ }^{18}$ Included in the art contest, 'the concours de l'an II' as it is called, were programs for buildings to accommodate citizens for different revolutionary events --primary assembly halls, theatres, covered arenas, and temples décadaires for rituals on the tenth day, the republican Sunday. ${ }^{19}$ Primary assembly halls were to be the meeting-place of citizens at the local level for political purposes. We have the plan for such a democratic enclosure by the well known architect, Jean-Jacques Lequeu (Fig. 11). ${ }^{20}$ On the outside the dome is decorated with a tricolour banner and a Phrygian bonnet. Over each doorway is a Level of Equality, reminding citizens that they are entering democratic space. Inside was to be an amphitheatre, also charged with revolutionary symbols.

The revolutionaries placed great importance on the theatre which they saw as a possible school for civic virtue, if plays with the proper messages were produced. Plays, moreover, could reach the illiterate masses. National theatres were among the civic buildings which the government called on architects to design for the contest. One such project has recently come to light among some previously uncatalogued designs in the Ecole des Beaux-Arts in Paris. The designer, CharlesEtienne Durand, an architect-engineer from the department of the Gard, envisaged a huge oval, neoclassical structure capable of accommodating nine to ten thousand spectators (Fig. 12). ${ }^{21}$ The auditorium inside exhibits exactly those features which one would expect after see- 
ing the changes which de Wailly introduced in the Odéon in Paris (Fig. 13). It is shaped so that the spectators could see each other. There are no balconies or boxes to divide the citizens from one another. On the ground level in the centre of the auditorium there is a large space with mobile benches which could be carried away for dances and other popular manifestations.

The plans for temples décadaires which have survived also are organized around amphitheatres. These temples were to provide accommodation for republican ceremonies on the tenth day which would feature revolutionary hymns, civic homilies, the reading of laws, and awards to outstanding citizens. The most impressive plan for such a temple is one designed by Jean-Nicolas-Louis Durand and Jacques Thibault (Fig. 14), ${ }^{22}$ the architects who won eleven prizes in the contest. They submitted two designs; this one seems to have been intended for the capital. ${ }^{23}$ The design shows a grandiloquent neoclassical edifice raised up on a broad substructure marked by huge columns at either end. The dome bears the outline of a map of the world, suggesting the world-wide significance of the Revolution. Superimposed on this is the inscription:

\section{RÉPUBLIQUE FRANÇAISE \\ LE PEUPLE FRANÇAIS RECONNAIT L'ÊTRE SUPREME ET L'IMMORTALITÉ DE L'AME}

From the cross-section of the building we can see that the dome was to be pierced with star-shaped apertures to give a cosmic dimension to the circular hall inside.

The contest called for plans to create covered arenas for revolutionary festivals on the site of the old opera house between the rue Bondi and the boulevards. The winning project by J.-B. La Hure featured a building containing an amphitheatre and linked to the street by a triumphal arch (Figs. 15, 16, 17) ${ }^{24}$ Another plan by the architect Riffault created an arena into which horses and festival floats could enter from the street (Figs. 18, 19). ${ }^{25}$ One of the most interesting projects was by an artist who rejected the site chosen by the government. From a register located recently in the archives this unsigned proposal can be attributed to the well-known architect Charles Percier. ${ }^{26} \mathrm{He}$ envisaged stands running along the left bank of the Seine, facing a parade ground demarked by triumphal arches at either end. These stands would enable a multitude of citizens to view processions along the shore and mock naval battles on the Seine. Above the stands was to be an edifice with three porticos, creating three temples (Fig. 20). The central temple was 
to contain an amphitheatre where ceremonies would reach their climax (Fig. 21).

Out in the provinces there were similar projects. A modest temple by an obscure architect by the name of Belu was intended for a small town. ${ }^{27}$ It features an austere rectangular building supporting a small cupola with a sundial on the top, again suggesting the universality of the Revolution (Fig. 22). The amphitheatre inside is decorated with revolutionary symbols, low-reliefs, and allegorical figures (Figs. 23, 24). In Montpellier during the Terror the representative of the Convention on mission, F.-A. Boisset, and the local popular society planned a huge Temple of Reason on the famous Place du Peyrou where a statue of Louis XIV had once stood..$^{28}$ Only fragments of this project survive, ${ }^{29}$ but there are a number of drawings for a similar temple by a local artist engineer called Dartain. ${ }^{30}$ These plans show an obsolescent style, but contain the familiar revolutionary allegorical figures and circular auditorium (Figs. 25, 26).

After the overthrow of Robespierre and his associates a conservative constitution was draughted, establishing the Directory in 1795 . This regime, like its predecessors, tried to use festivals to rally the citizenry around the shaky republic. Rarely did those fettes arouse the sort of enthusiasm that had marked the Festival of Federation. Contibuting to the waning of revolutionary festivals was the revival of Catholicism and the fact that republican ceremonies had to share the use of churches. The frustration of republican planners is revealed in attempts such as that in Orléans to create an amphitheatre in a church in complete contradiction of its cruciform shape (Fig. 27). ${ }^{31}$ Nevertheless, there were still ambitious proposals for amphitheatres in Paris and the provinces. Many of the thirty-odd projects submitted to a contest for the site of the Château Trompette in Bordeaux at the end of the Directory featured a huge amphitheatre. For example, Combes planned a long amphitheatre running up from the river Garonne (Fig. 28), ${ }^{32}$ and an engineer by the name of Blein proposed a huge circus at the end of an axis beginning on a place on the riverfront (Figs. 29, 30). ${ }^{33}$

Despite all this planning, the revolutionaires did not succeed in creating the special spaces where citizens would electrify each other. There are echoes of their visions in the twentieth century, for instance in the plans of the present French government for a popular opera house and a stade de Rock. However, were the revolutionaries able to return from wherever they are, they would be disappointed. Hitler's architects planned to use similiar ideas of mass psychology for party rallies. The party hall in Nuremburg recalls projects of the French Revolution. But the main descendent is the modern sports bowl where the masses as- 
semble, not around the autel de la patrie, but an inflated pigskin. Moreover, the masses are not united, but divided into supporters of rival teams who sometimes battle each other, as in Brussels last summer. We have been discussing one of the dreams of the Revolution, a dream which has largely vanished, as dreams are likely to do, in the light of reality.

JAMES A. LEITH

Queen's University

\section{NOTES}

1. Anatole Kopp, Ville et révolution. Architecture et urbanisme soviétique des années vingt, Paris, 1967.

2. Barbara Miller Lane, Architecture and Politics in Germany, 1918-1945, Harvard, 1968.

3. Robert R. Taylor, The Word in Stone: The World of Architecture in National Socialist Ideology, Berkeley, 1974.

4. Jean Starobinski, 1789, Les Emblèmes de la Raison, Paris, 1973. Recently more work has been done on architecture during the Revolution: Daniel Rabreau has been studying theatres during the period, Mark Deming is doing a major study of proposed squares in honour of Louis XVI which end in 1791, and Claudine de Vaulchier is examining proposals for National Assemblies, and Werner Szambien plans to publish a book on the contest of Year II.

5. Réverchon is wrongly dated in G.-E. Allais, A. Détournelle, and A.-L.-T. Vaudoyer, Grands prix d'architecture ... Paris, 1806, where it is confused with projects done in 1782 to celebrate the birth of a Dauphin the previous year. In 1787 the project was 'un hippodrome.' Procès Verbaux de l'Académie d'architecture, ed. H. Lemonnier, Paris, 1911-1929, 10 vols., vol. IX, p. 203.

6. Abbé Brotier, 'Premier mémoire sur les jeux du cirque, considérés dans les vues politiques des Romains. Lû janvier 1781,' Histoire de l'Académie des inscriptions et belles-lettres ... 1780-1784, vol. 45, Paris, 1793, pp. 478-494, 'Second Mémoire ...' pp. 495-508; 'Troisième Mémoire ...' pp. 509-524.

7. Jacques-François Boulée, Architecture. Essai sur l'art, édition complétée par quelques documents in édits, avec une introduction et des notes de J.-M. Pérouse de Montclos, Paris, 1968, pp. 68-71.

8. Richard A. Etlin, 'Architecture and the Festival of Federation, Paris 1790,' Architectural History, vol. XVIII, 1975, pp. 23-42. See too Daniel Rabreau, 'Architecture et fête dans la nouvelle Rome. Notes sur l'esthétique urbaine de la fin de l'Ancien Régime et de la Révolution,' Les Fêtes de la Révolution. Colloque 
de Clermont-Ferrand (juin 1974) ed. Jean Ehrard and Paul Viallaneix, Paris, 1977, pp. 355-375.

9. Armand-Guy Kersaint, Discours sur les monuments publics, prononcé au conseil du département de Paris, le 15 décembre 1791 ... Paris, 1792.

10. Ibid., pp. vi-vii.

11. Bibliothèque Municipale, Bordeaux. Fonds Delpit, Série B Estampes, Carton 13, No. 14.

12. On November 20, 1792 the General Council of the Commune called on artists to submit proposals about how the public garden could be transformed to serve a new purpose. Lagarde, a municipal official reported on December 15. The Council did not take any action, but reconsidered the report on April 28, 1793. Lagarde, Rapport ... Arch. Mun. Bordeaux M3.

13. Ibid., p. 22.

14. The register of decrees of the Committee of Public Safety concerning public works contains a copy of the decree of 20 ventôse an II (March 10, 1794) ordering conversion and enlargement of the theatre into a Théâtre du Peuple to present revolutionary plays for the common people. Arch. Nat. AF II ${ }^{*}$ 133, p. 27. Later it was called the Theatre du Peuple. A report on the changes by de Wailly is in Arch. Nat. $\mathrm{F}^{14} 187^{\mathrm{b}}$.

15. There are two sets of drawings showing the internal changes. One is in Arch. Nat. Cartes et Plans, Versement d'architecture, Boite 17. The other is in the Bibl. de la Comédie française, Carton Leclerc. The latter collection has cross sections and plans for the semi circular place in front of the theatre.

16. In a letter dated 16 prairial an II (June 4, 1794) de Wailly reported to the Committee of Public Safety that he would have completed all the internal changes by 19 prairial, one day ahead of the date they had set. Arch. Nat. $\mathrm{F}^{17}$ 1326, doss. 14.

17. On the geometry of the theatre, the place and the adjacent streets see Monika Steinhauser and Daniel Rabreau, 'Le Théâtre de l'Odéon de Charles de Wailly et Marie-Joseph Peyre 1767-1782,' Revue de l'art, no. 19, 1973, pp. 9-49. See pl. 22.

18. On the scope of the program see James A. Leith, The Idea of Art as Propaganda in France 1750-1799, Toronto 1965, reprinted 1969, pp. 119-128; Media and Revolution: Moulding a New Citizenry in France during the Terror, Toronto, 1968, reprinted 1974, passim; and 'Space and Revolution: Architectural and Urban Planning during the Terror,' Proceedings of the Consortium on Revolutionary Europe, 1980, Duke University Press, 2 vols. vol. II, pp. 28-43.

19. Arrêtés du comité de salut public relatifs aux monuments publics, aux arts et aux lettres, n.d. n.p., Bib. Nat. Imp. Lb 1092.

20. Bibl. Nat. Estampes, $\mathrm{Ha} 80^{2}$, tome $1, \mathrm{pl} 4$. The register of the Inspecteurs de la Salle (of the Convention) recorded items including projects for the Contest of Year II, as they arrived. On 30 Messidor an II (July 18, 1794) Lequeu delivered a 'monument destiné à l'exercise de la souverainété du peuple ...', Arch. Nat., $D^{*} X X X V^{C}$, vol. 1, no. 1885.

21. Ecole Nationale Supérieure des Beaux-Arts, No. 18272. 
22. Mus. Carnavalet Architecture Anonyme TGC, D8208. Although classified as 'anonymous' there is no doubt that it is by Durand and Thibault. Works for the contest were unsigned so that there would be no favoritism.

23. The register mentioned in fn. 20 , records that Durand and Thibault submitted two 'décadaires' and nine other projects on 30 Messidor an II (July 18, 1794), $\mathrm{D}^{*} \mathrm{XXXV}^{\mathrm{c}}$, vol. 1, no. 1891. Both temples décadaires won prizes, one worth 6000 1., the other 4000 1. Jury des arts. Prix décernés aux projets d'architecture ... Paris n.d. bibl. Nat., Estampes, Coll. Deloynes, vol. LVI, no. 1735. What appears to be the smaller of the two was published by G.-E. Allais, A. Détournelle, and A.-L.-T. Vaudoyer, Grands Prix d'architecture ... Paris, 1806, pls. 31 and 32.

24. Allais, Détournelle and Vaudoyer, Grands Prix ... pl. 24, 25(2), and 26(2).

25. Ecole National Supérieure des Beaux-Arts, Nos. 1842 and 1843.

26. The design can be attributed to Percier because he alone entered a project on 10 prairial an II (May 29, 1794) for 'arrenes (sic) sur le bord de la Seine côté

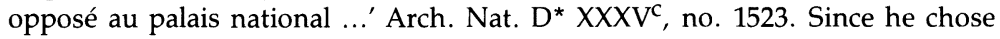
a site other than that specified for the contest, his project was listed under 'Divers projets d'embellissemens pour Paris' in the list of works for the contest when they were displayed, Notice des ouvrages de sculpture, architecture et peinture exposés aux concours ... Paris, n.d. Bibl. Nat. Estampes, Coll. Deloynes, no. 1724.

27. Belu described himself as 'ingénieur à Montereau.' His project was received by the Committee of Public Safety on 26 thermidor an II. Arch. Nat. F ${ }^{13} 571$.

28. The plan was announced in a letter, dated 28 pluviôse an II (February 16, 1794), from Boisset to the Convention where it was reported on 11 Ventôse an II (March 1, 1794). Journal de Paris, 12 Ventôse an II, no. 426, p. 1721. It was reproduced in several other newspapers for instance the Annales patriotiques et littéraires, 12 Ventôse an II, no CCCCXXV, pp. [1897] - 98.

29. Arch. Nat. Cartes et Plans, N III Hérault 24. Two ground plans by Moulinier one showing the place with the château d'eau at the end, the other showing what appears to be a circular temple with a statue in the centre, conforming roughly to the planned Temple of Reason which was to have a statue of Philosophy by Pajou at the focal point. For the circumstances see Arch. Dépt. de l'Hérault, L 1354, 3492 and 5521.

30. The designs are in the Société archéologique de Montpellier. On the Temple, see Louis Grasset-Morel, Le Temple de la Raison et les colonnes de la Liberté à Montpellier ... Montpellier, 1901. See too the catalogue of the exhibition, Projets et dessins pour la Place Royale du Peyrou à Montpellier, Inventaire Général des Monuments et des Richesses Artistiques Lanquedoc-Roussillon, Caisse Nationale des Monuments Historiques et des Sites, 1983.

31. Arch. Nat. $F^{13} 729$, dossier Loiret.

32. Bibl. Mun. Bordeaux. Fonds Delpit, Série B Estampes, Carton 12, \#5.

33. Arch. Nat. $F^{13} 1713$ 
1 Réverchon, Elevation of a Hippodrome, Bibliothèque Nationale, imprimés (Photo: B.N. Service Photographique).

2 Réverchon, Ground-plan of a Hippodrome, Bibliothèque Nationale, Imprimés (Photo: B.N. Service Photographique).

3 Etienne-Louis Boullée, Plan for a Cirque. Elevation and cross-section. Bibliothèque Nationale, Estampes (Photo: B.N. Service Photographique).

4 Mandar, View of the Champ de Mars on July 14, 1790, Bibliothèque Nationale, Estampes (Photo: B.N. Service Photographique).

5 Armand-Guy Kersaint, Amphitheatre for the Champ de Mars, Bibliothèque Nationale, Imprimés (Photo: Service Photographique).

6 Louis Combes, Ground-plan of a Cirque National for Bordeaux, Bibliothèque Municipale de Bordeaux, Fonds Delpit (Photo: Joubert).

7 Charles de Wailly, Conversion of the ground-floor of the Odéon, Archives Nationales, Cartes et Plans (Photo: A.N., Service Photographique).

8 Geometrical lay-out of the Odéon. (Lower small circle represents the auditorium, the upper small circle represents the stage and back-stage.)

9 Charles de Wailly, Transformation of the Place in front of the Odéon into an arena, Bibliothèque de la Comédie française,) (Photo: Josse).

10 Charles de Wailly, The Place in front of the Odéon covered with canvas, Bibliothèque de la Comédie française (Photo: Josse).

11 Jean-Jacques Lequeu, Plan for a Primary Assembly, Bibliothèque Nationale, Estampes (Photo: B.N. Service Photographique).

12 Charles-Etienne Durand, Elevation of a Revolutionary Theatre, Ecole Nationale Supérieure des Beaux-Arts (Photo: ENSBA Service Photographique).

13 Charles-Etienne Durand, Ground-plan of a Revolutionary Theatre, Ecole Nationale Supérieure des Beaux-Arts (ENSBA Service Photographique).

14 Jean-Nicolas-Louis Durand and Jacques Thibault, A Temple Décadaire, Musée Carnavalet (Photo: Josse).

15 J.-B. Lahure, Elevation of a Covered Arena, Bibliothèque Nationale, Imprimés (Photo: B.N. Service Photographique).

16 J.-B. Lahure, Ground-plan of a Covered Arena, Bibliothèque Nationale, Imprimés (Photo: B.N. Service Photographique). 
17 J.-B. Lahure, Cross-section of a Covered Arena, Bibliothèque Nationale, Imprimés (Photo: B.N. Service Photographique).

18 Riffault, Cross-section, front view, and rear-view of a Covered Arena, École Nationale Supérieure des Beaux-Arts (Photo: Service de Documentation Photographique de la Réunion des Musées Nationaux).

19 Riffault, Ground-plan of a Covered Arena showing a Cirque, École Nationale Supérieure des Beaux-Arts (Photo: Service de Documentation Photographique de la Réunion des Musées Nationaux).

20 Charles Percier, Elevation of the Temples containing Covered Arenas, Musée Carnavalet (Photo: Josse).

21 Charles Percier, Ground-plan of the three Temples, Musée Carnavalet (Photo: (Josse).

22 Belu, Elevation of a Temple Décadaire for a provincial town, Archives Nationales (Photo: A.N. Service Photographique).

23 Belu, Ground-plan of a Temple Décadaire for a provincial town, Archives Nationales (Photo: A.N. Service Photographique).

24 Belu, Cross-section of a Temple Décadaire for a provincial town, Archives Nationales (Photo: A.N. Service Photographique).

25 Dartain, Elevation of a Temple to the Supreme Being, Société Archéologique de Montpellier, (Photo: Secrétariat Régional des Monuments et des Richesses Artistiques de Languedoc-Roussilon).

26 Dartain, Ground-plan of a Temple of Reason, Société Archéologique de Montpellier (Photo: Secrétariat Régional des Monuments et Richesses Artistiques de Languedoc-Roussilon).

27 Anon., Plan to create an amphitheatre in the Cathedral of Orléans, Archives Nationales (Photo: A.N. Service Photographique).

28 Louis Combes, Plan for the site of the Château-Trompette in Bordeaux, Bibliothèque Municipale de Bordeaux, Fonds Delpit (Photo: Joubert).

29 Blein, Project for the site of the Château-Trompette in Bordeaux, Archives Nationales (Photo: A.N. Service Photographique).

30 Blein, Detail of a project for the site of the Château Trompette in Bordeaux, Archives Nationales (Photo: Service Photographique). 


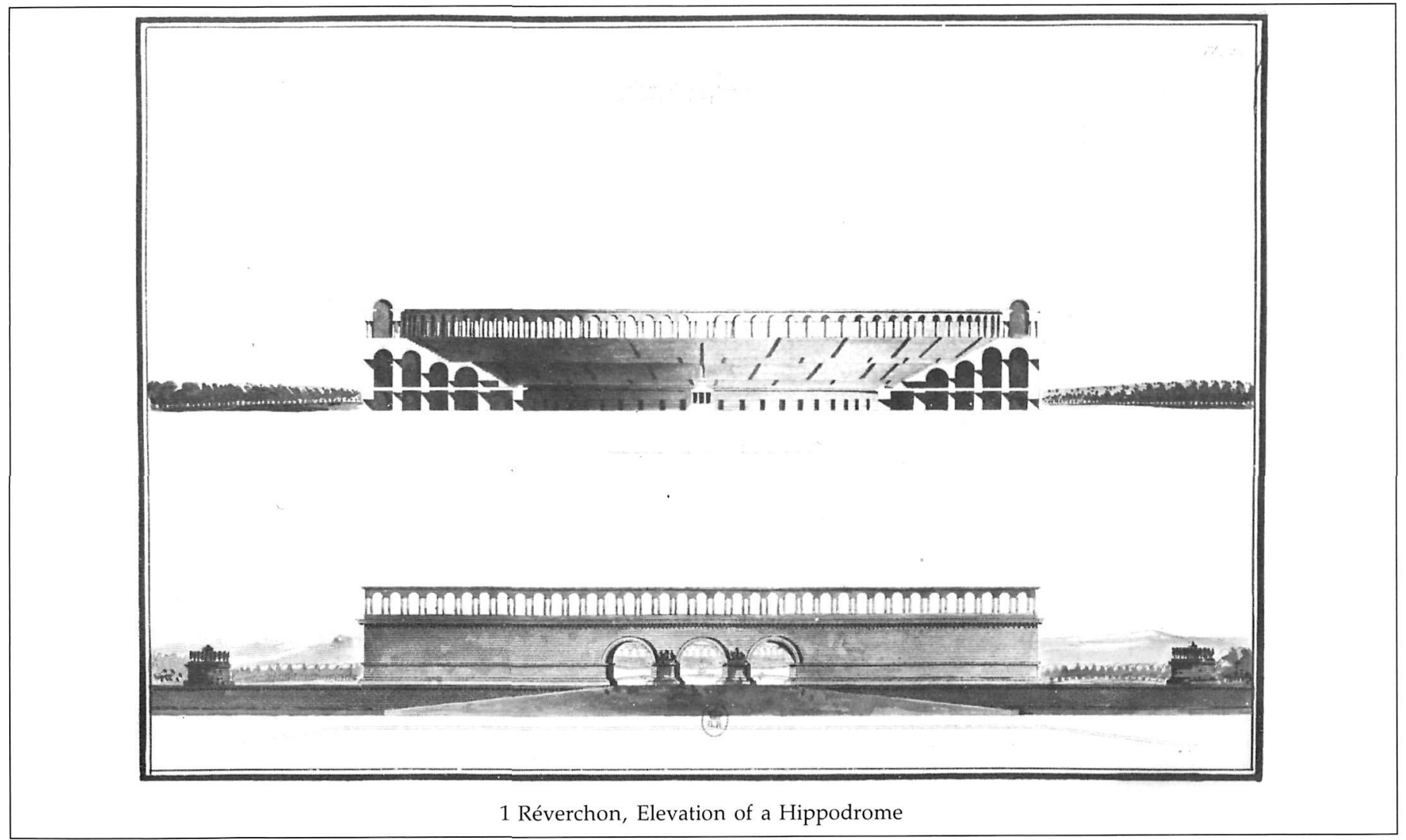




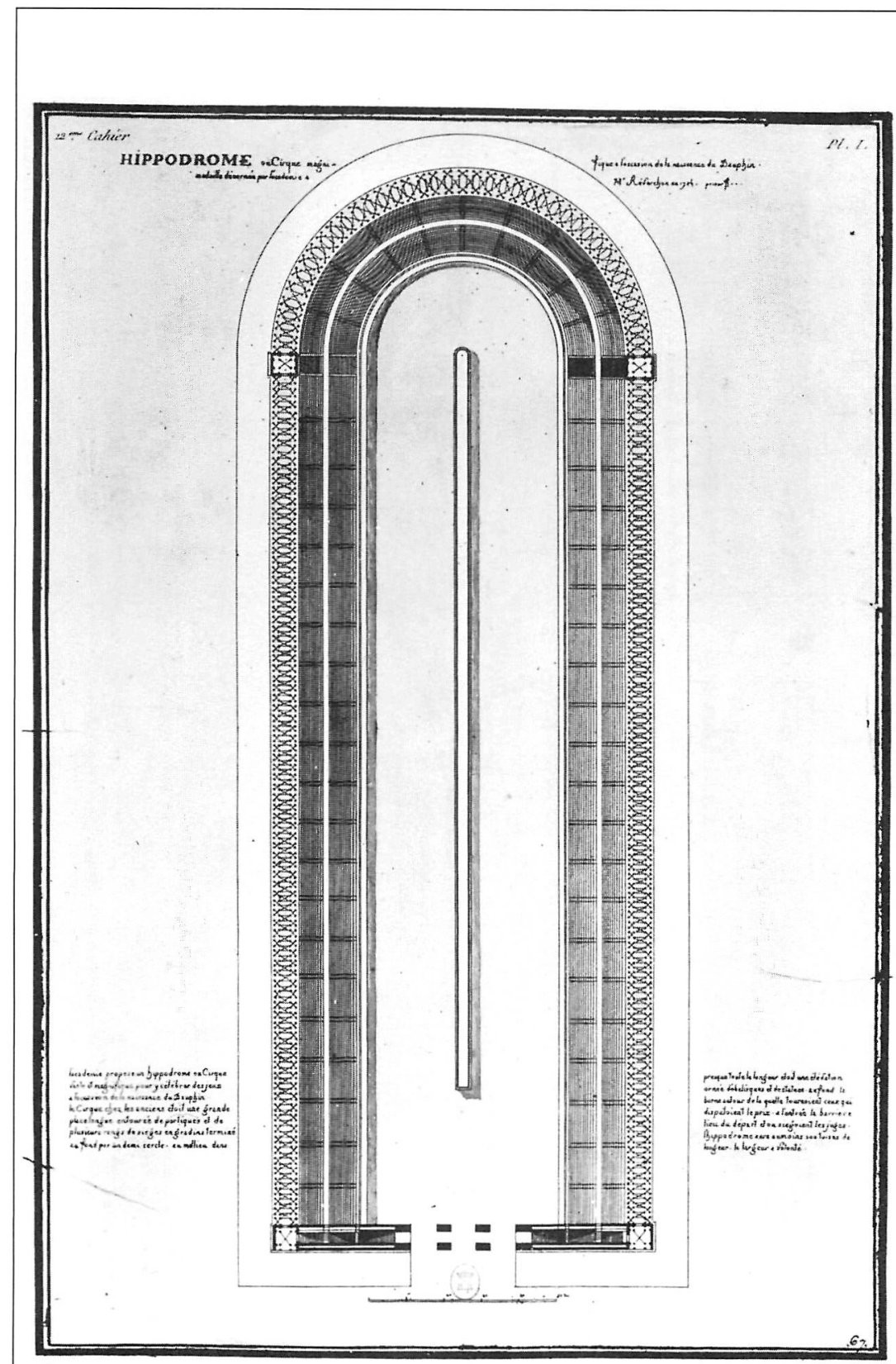

2 Réverchon, Ground-plan of a Hippodrome 


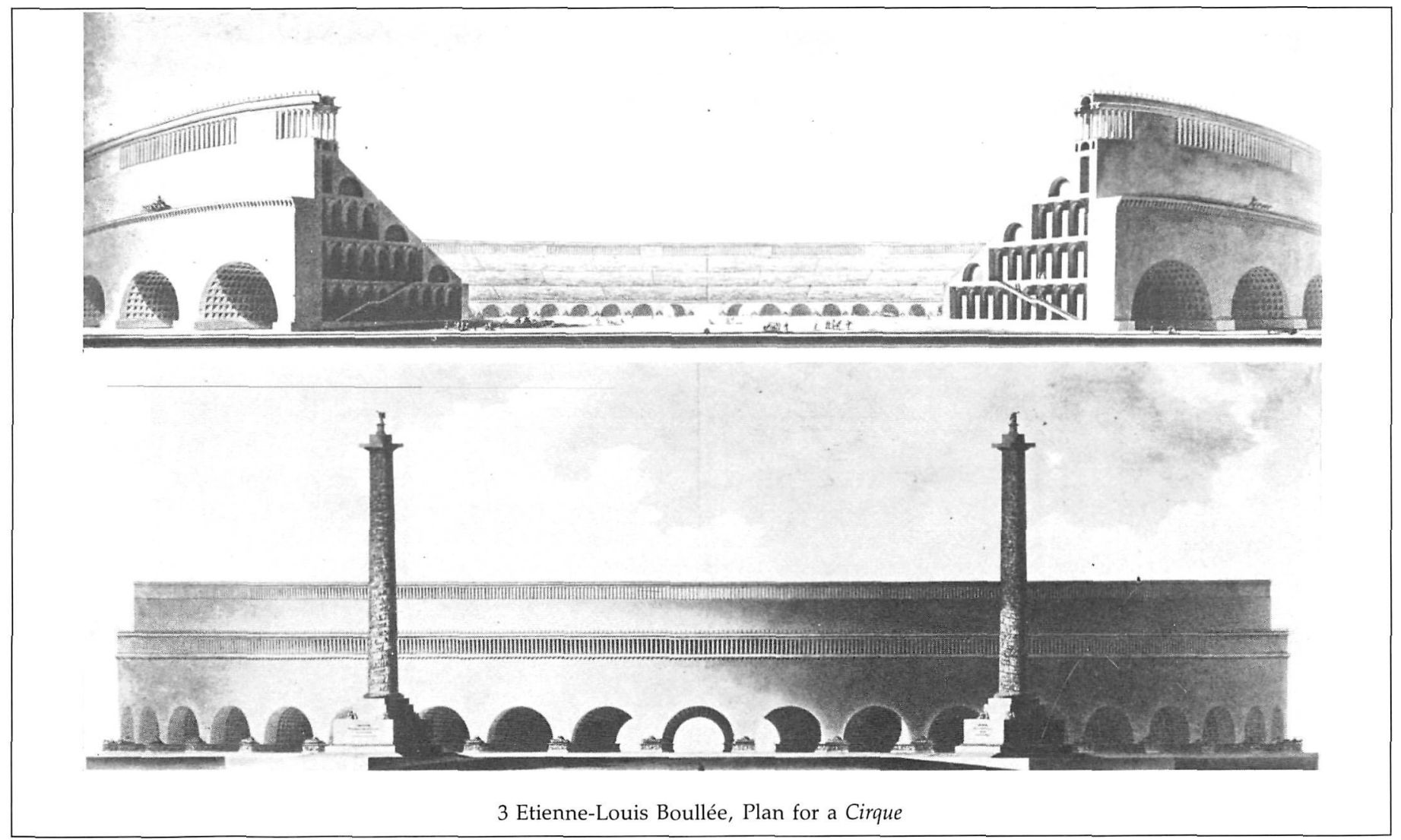




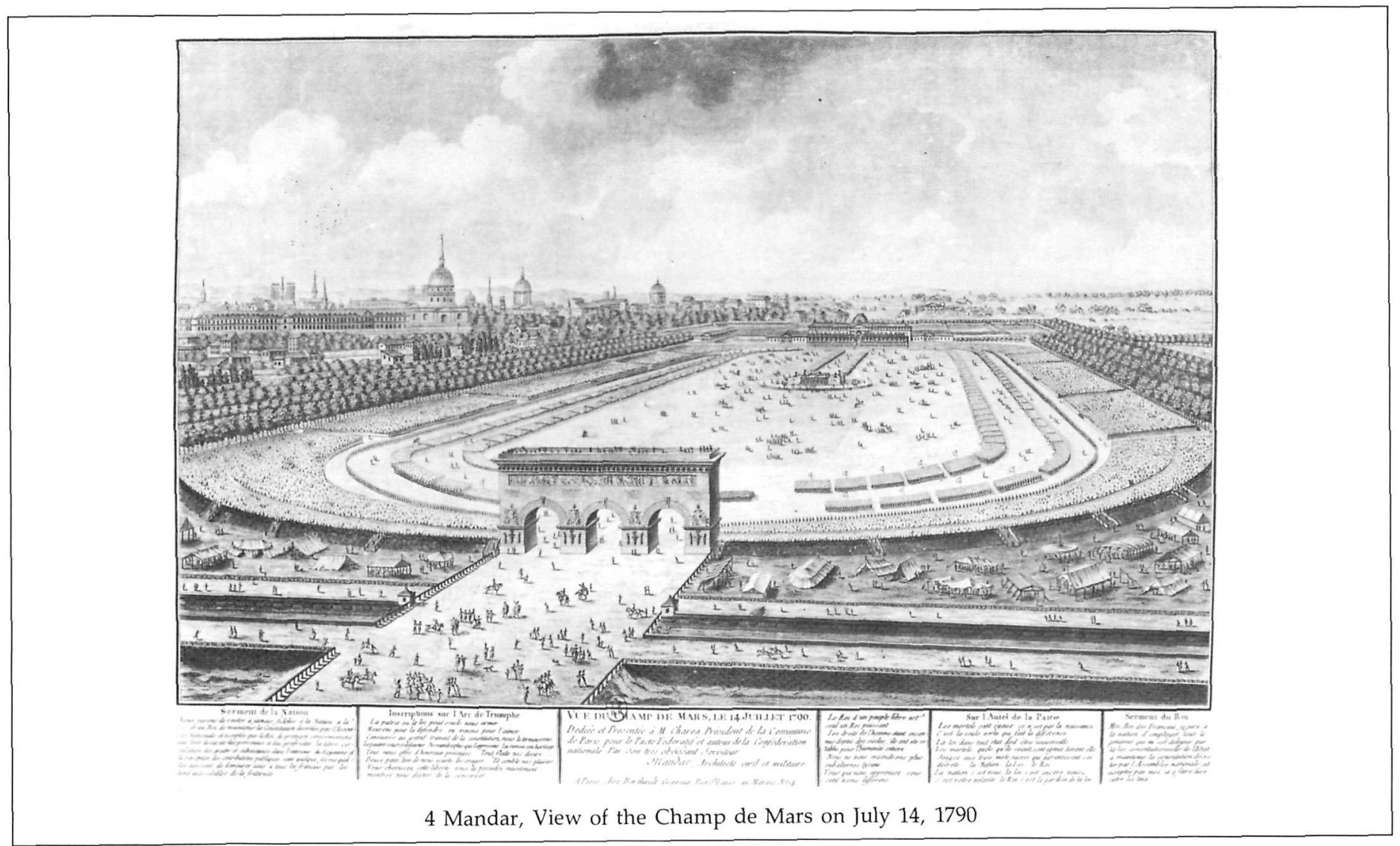




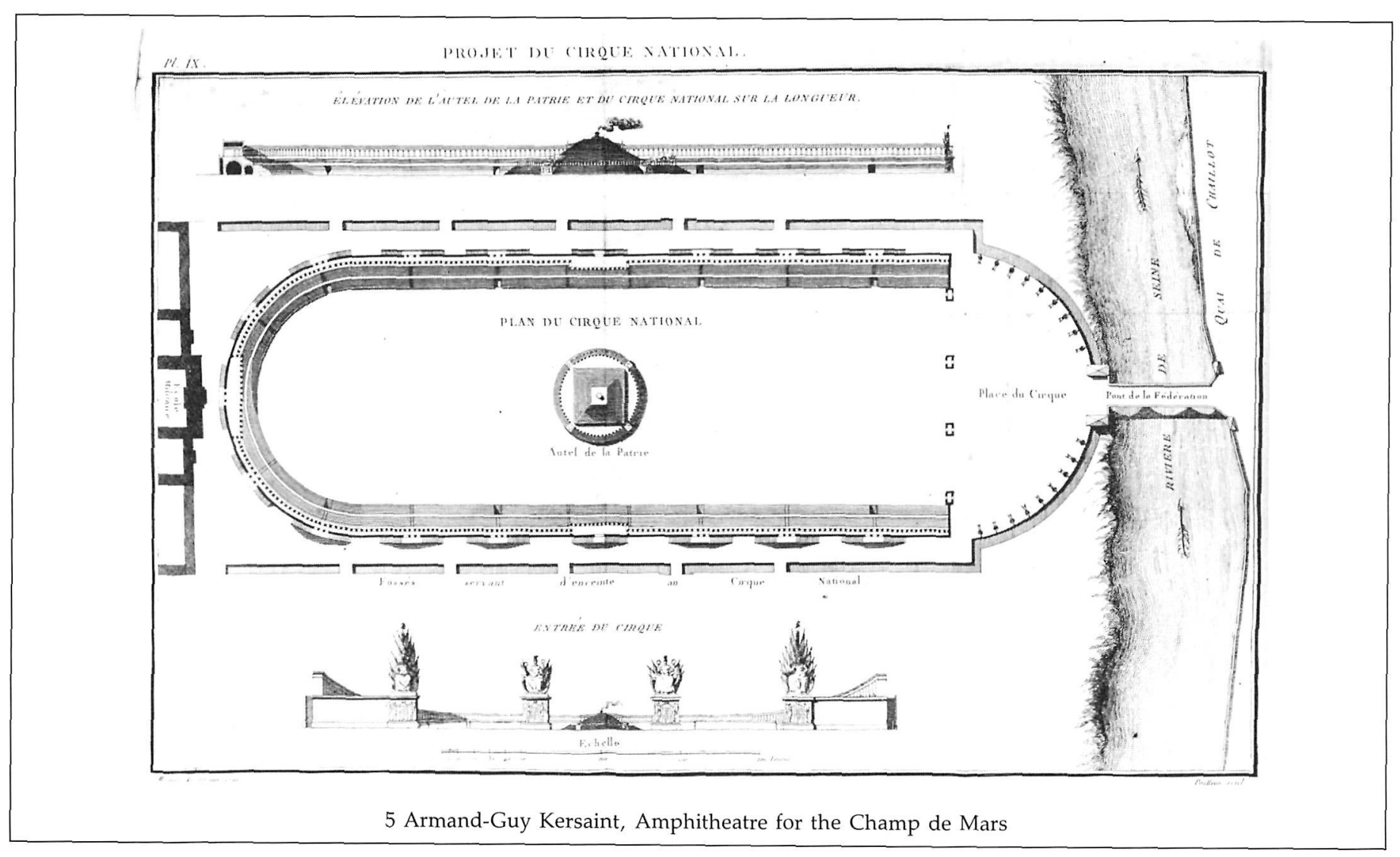




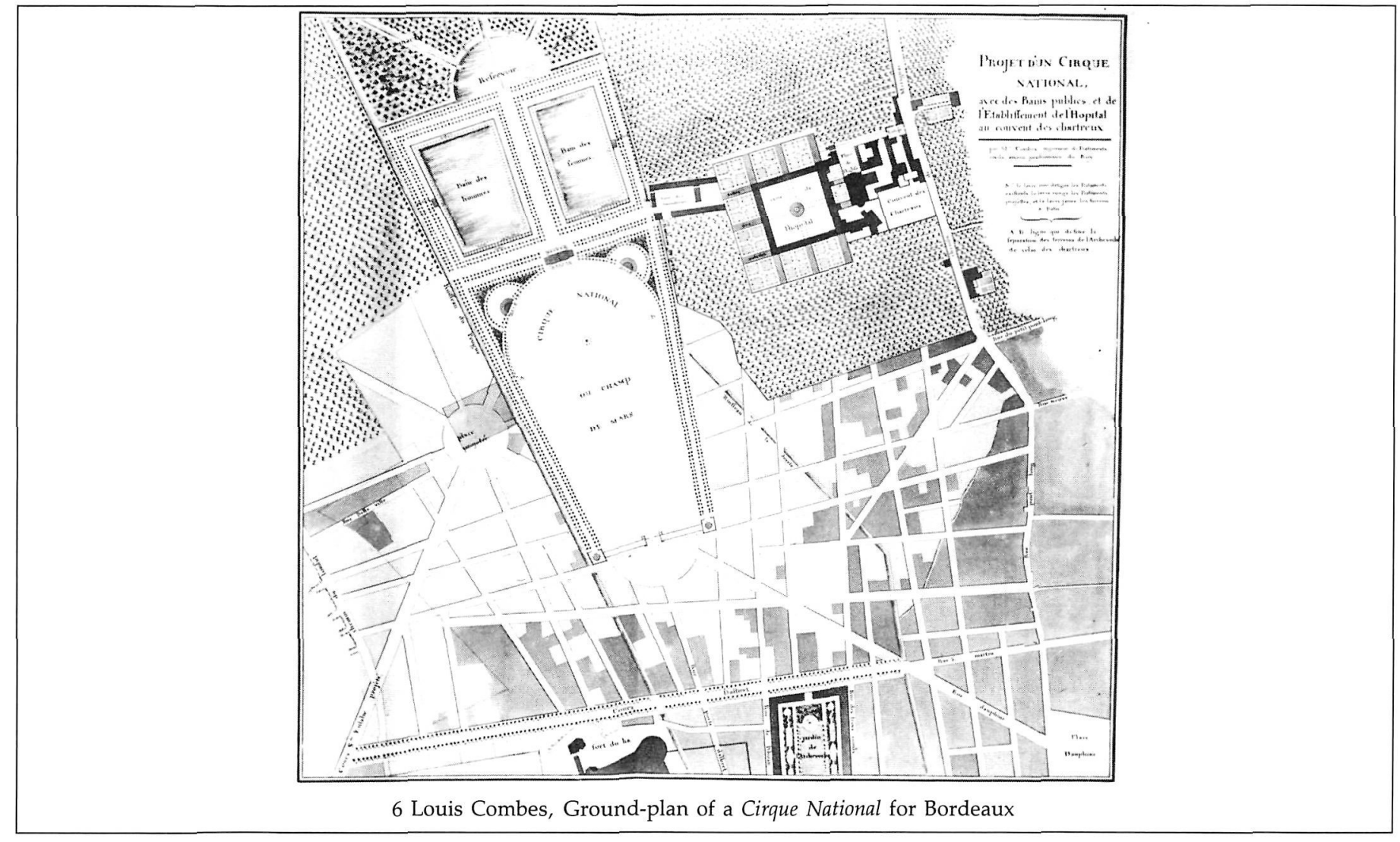




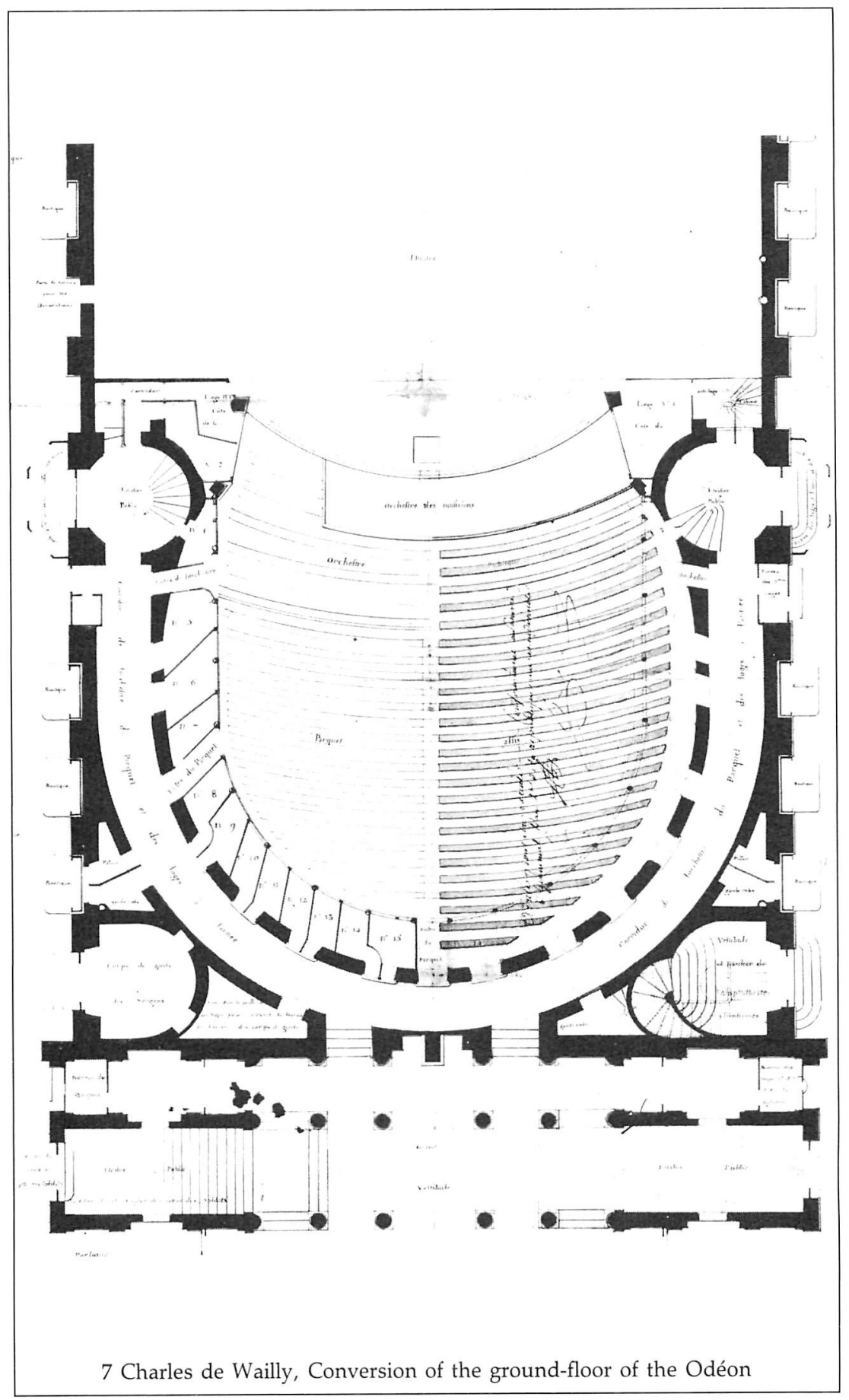




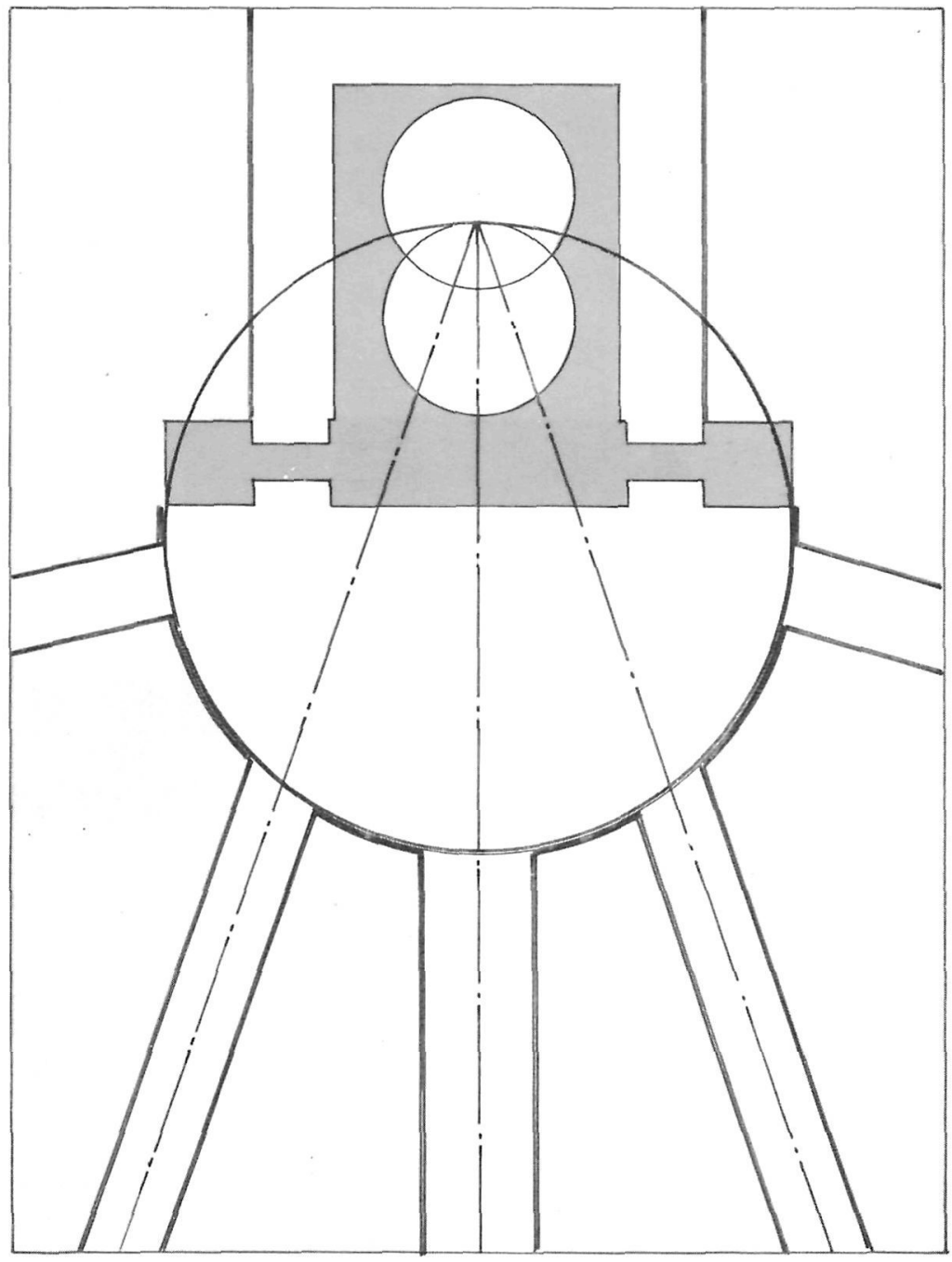

8 Geometrical lay-out of the Odéon. (Lower small circle represents the auditorium, the upper small circle represents the stage and back-stage) 


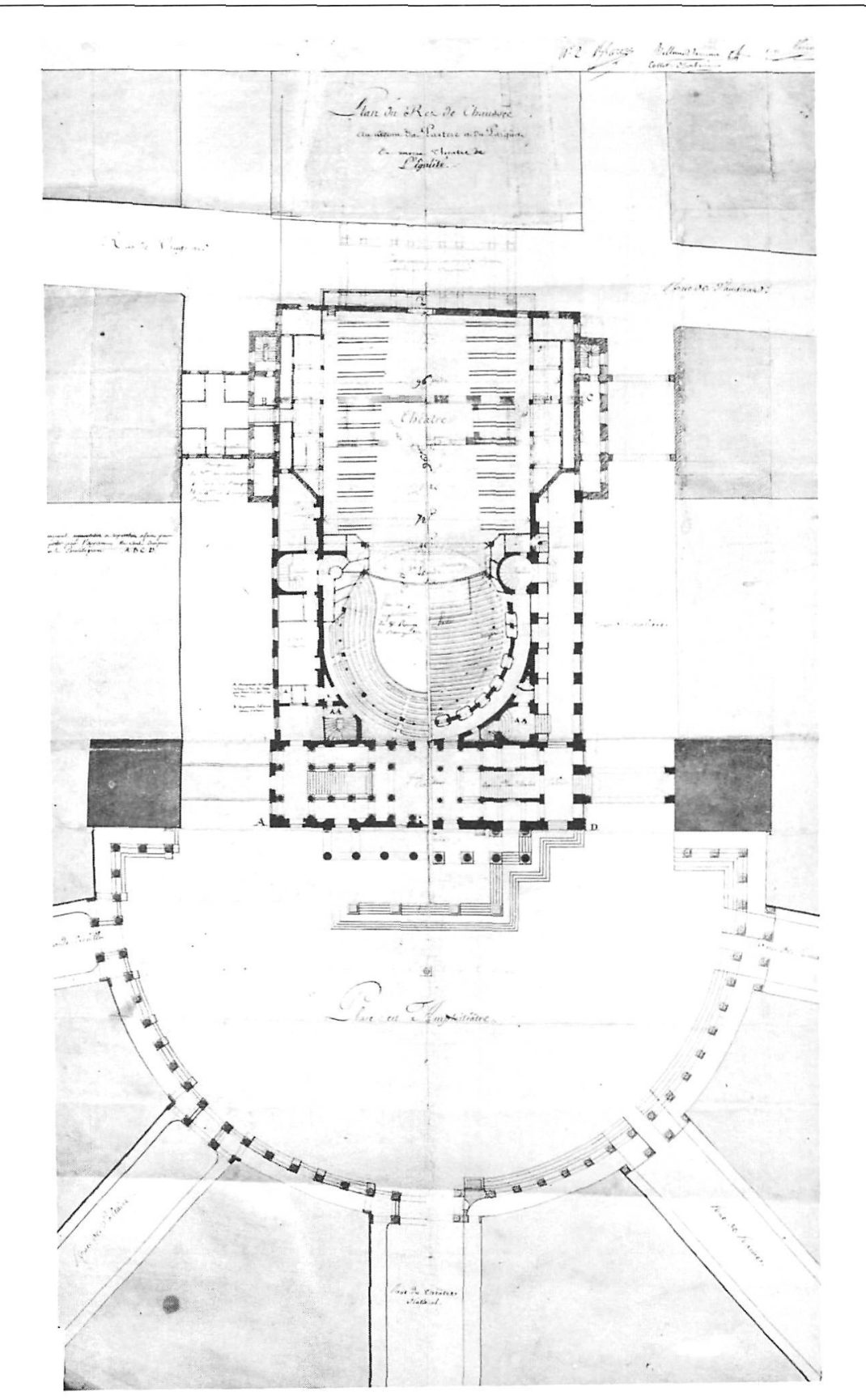

9 Charles de Wailly, Transformation of the Place in front of the Odéon into an arena 


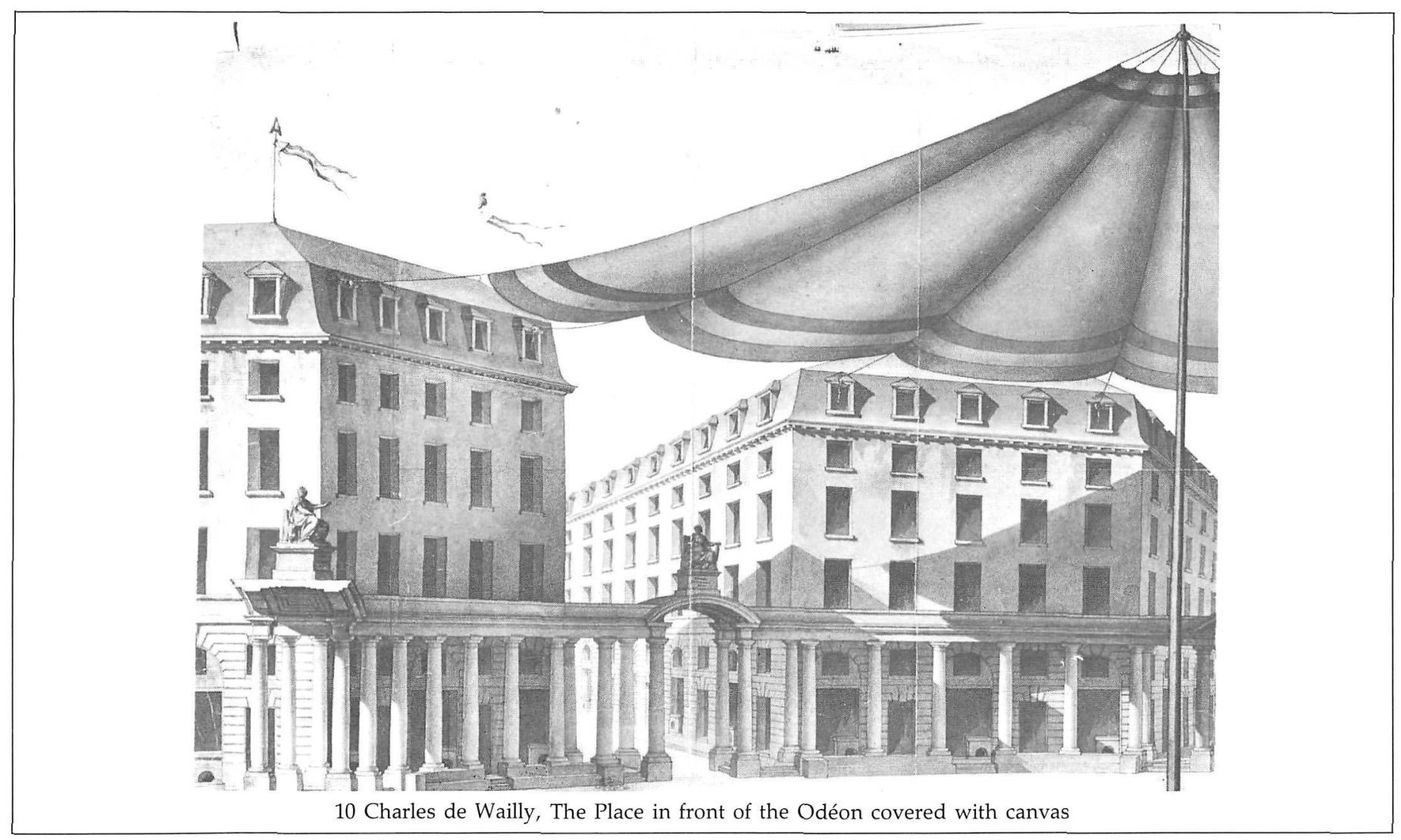




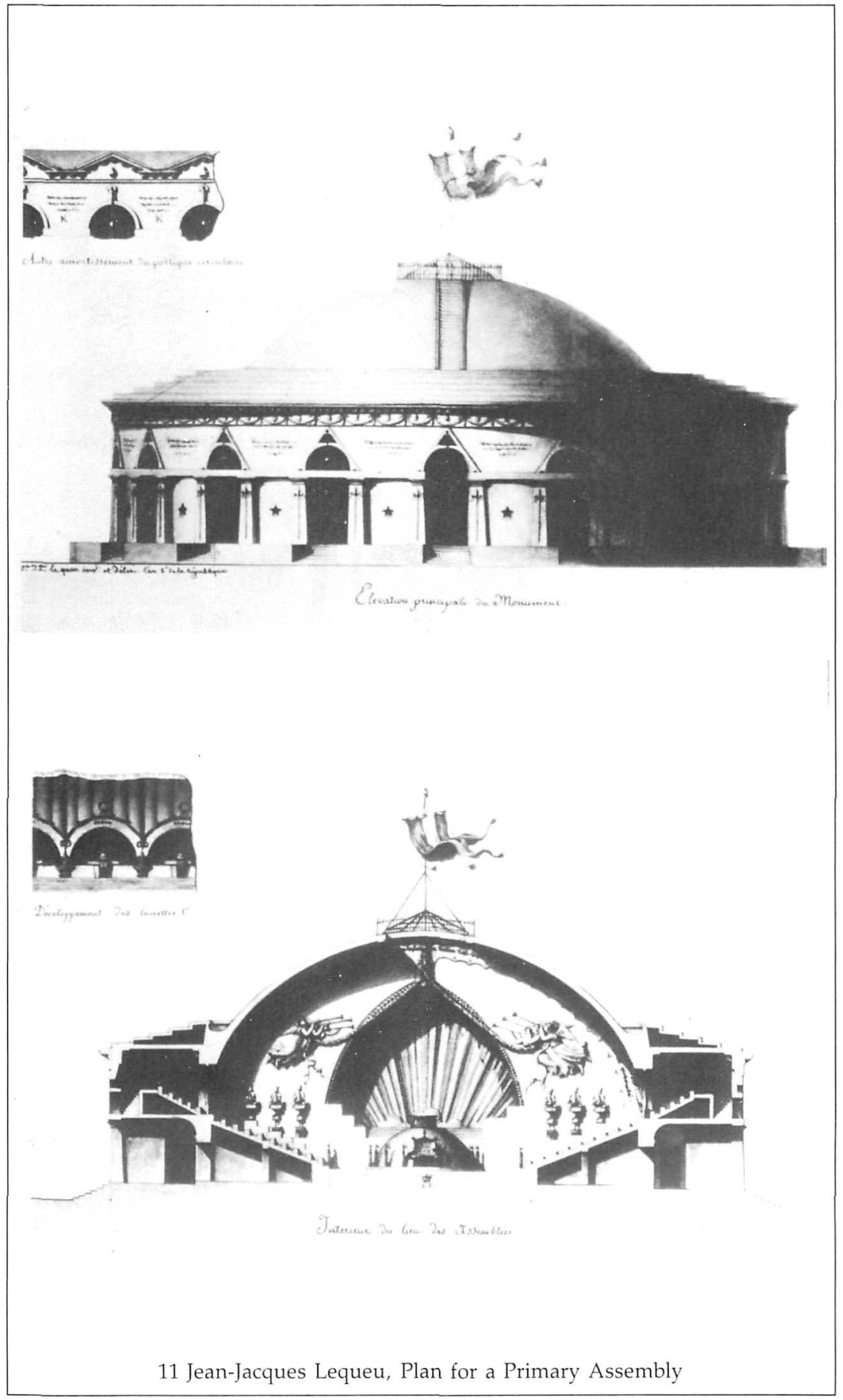




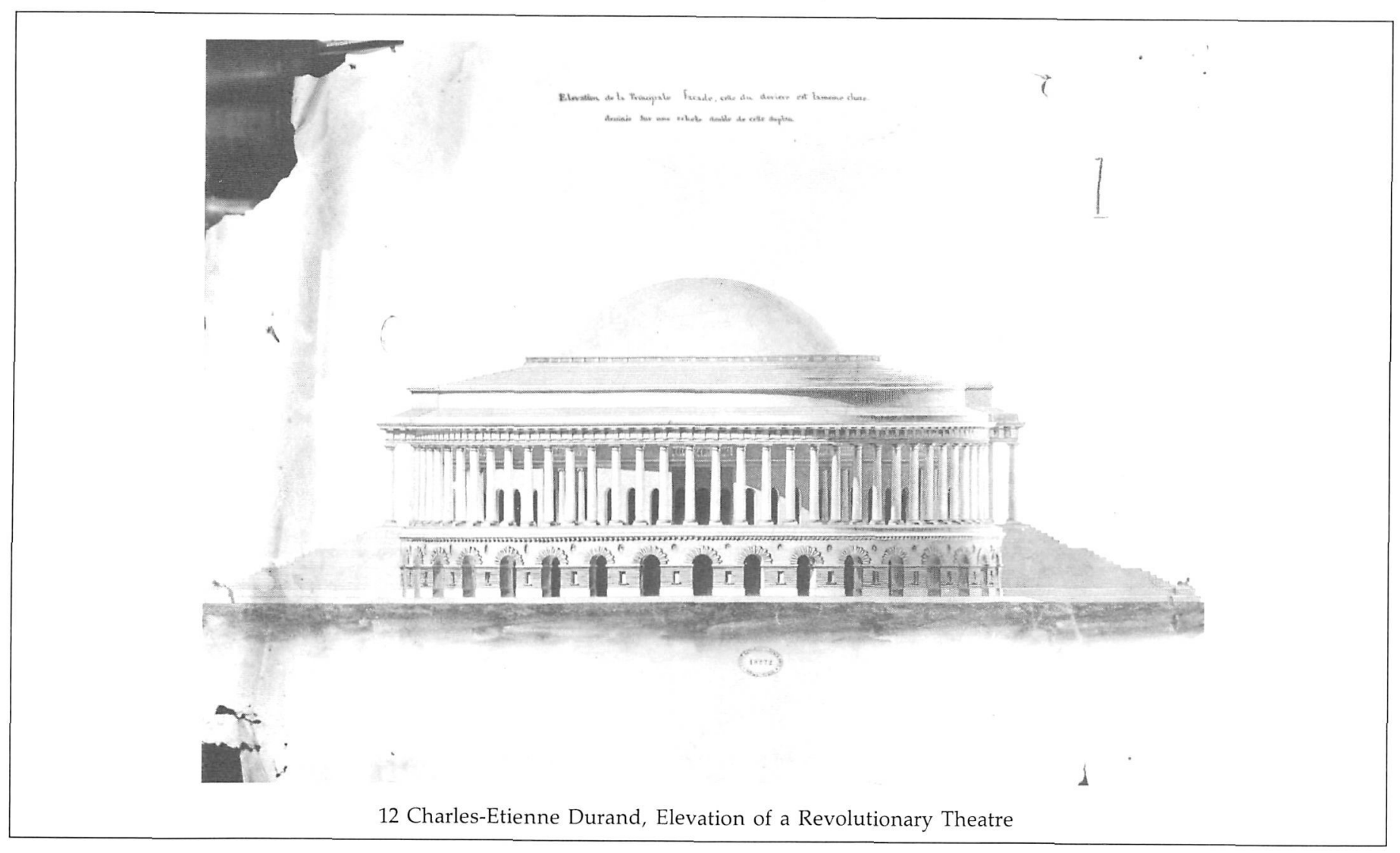




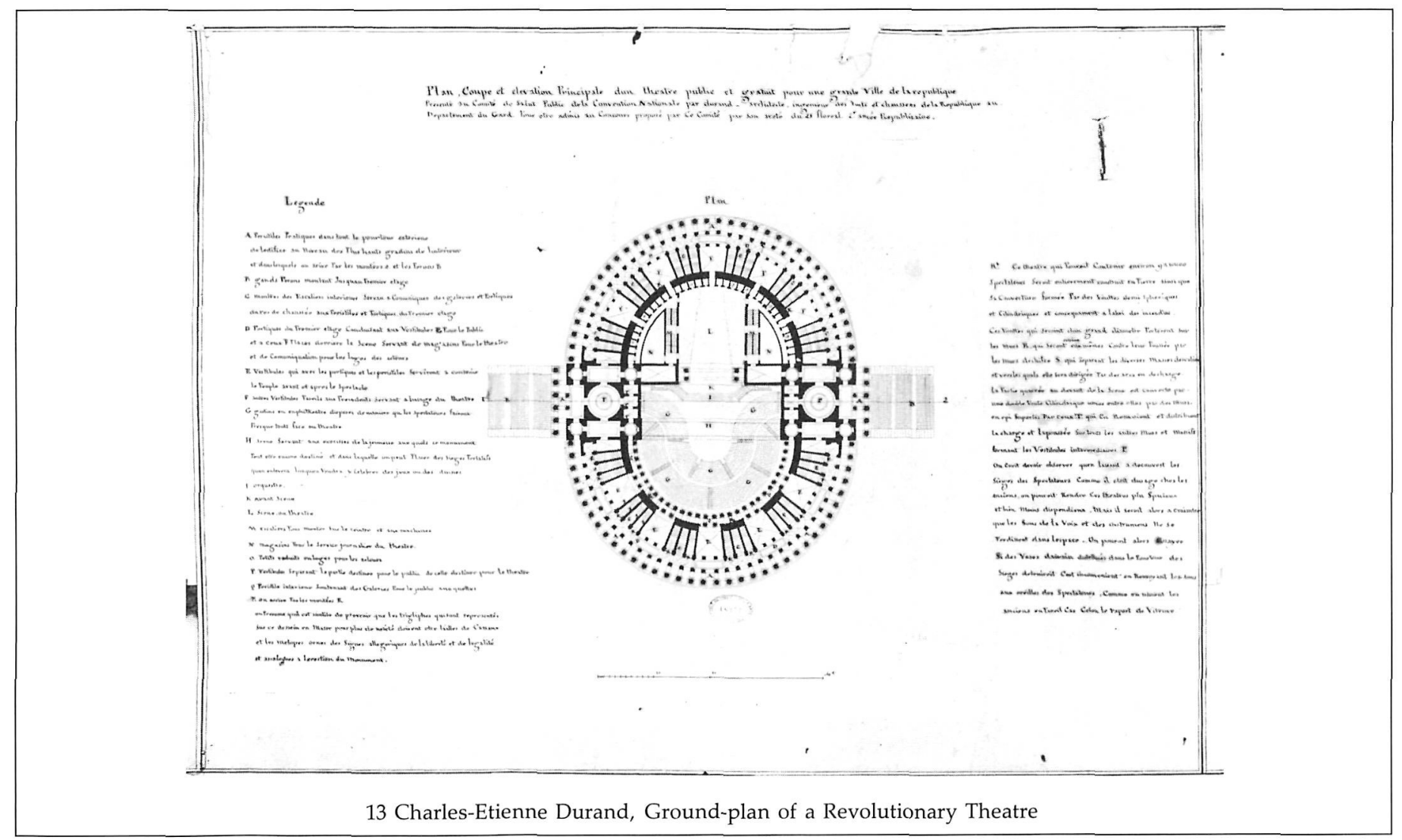

్ㅛㅇ 


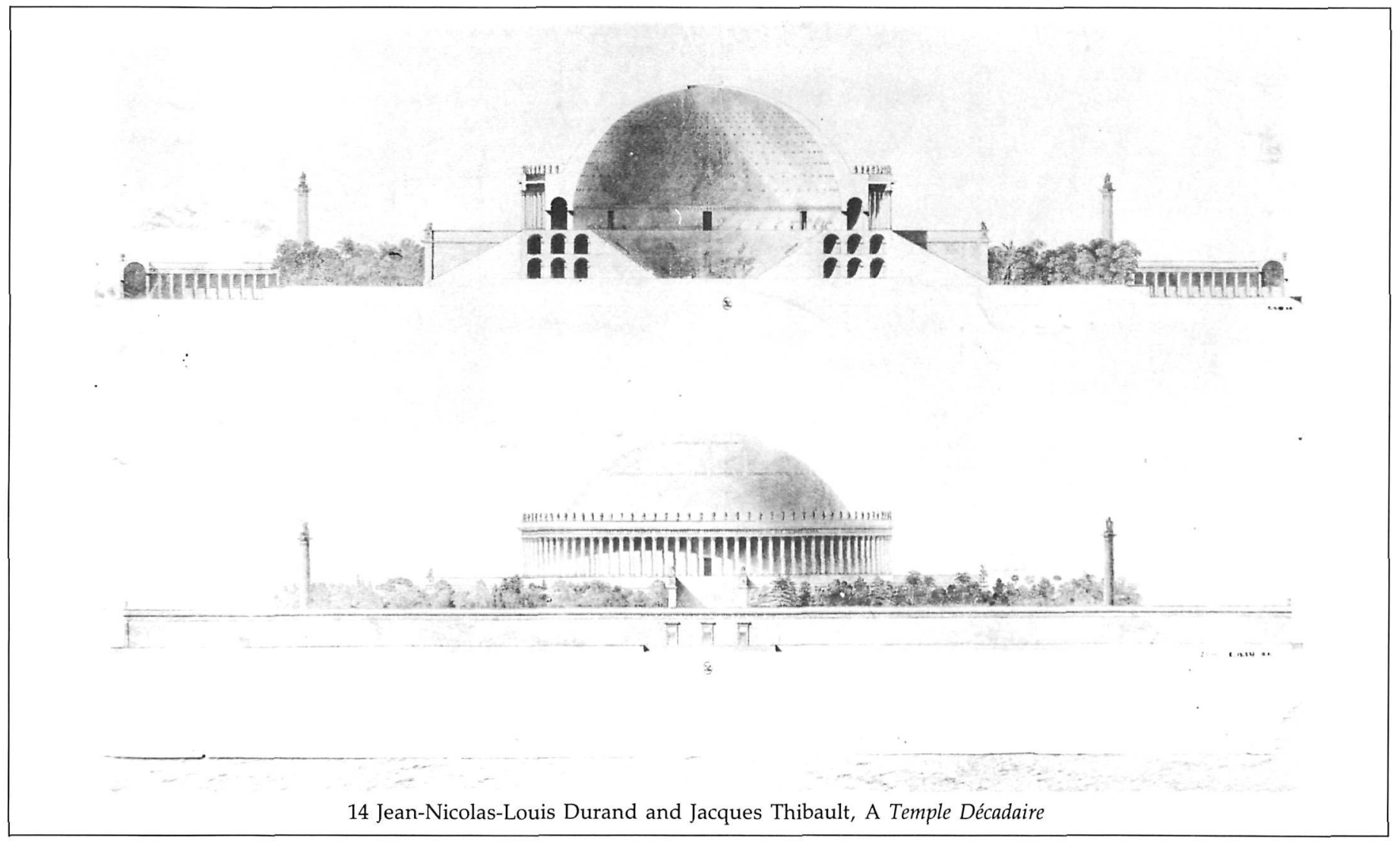




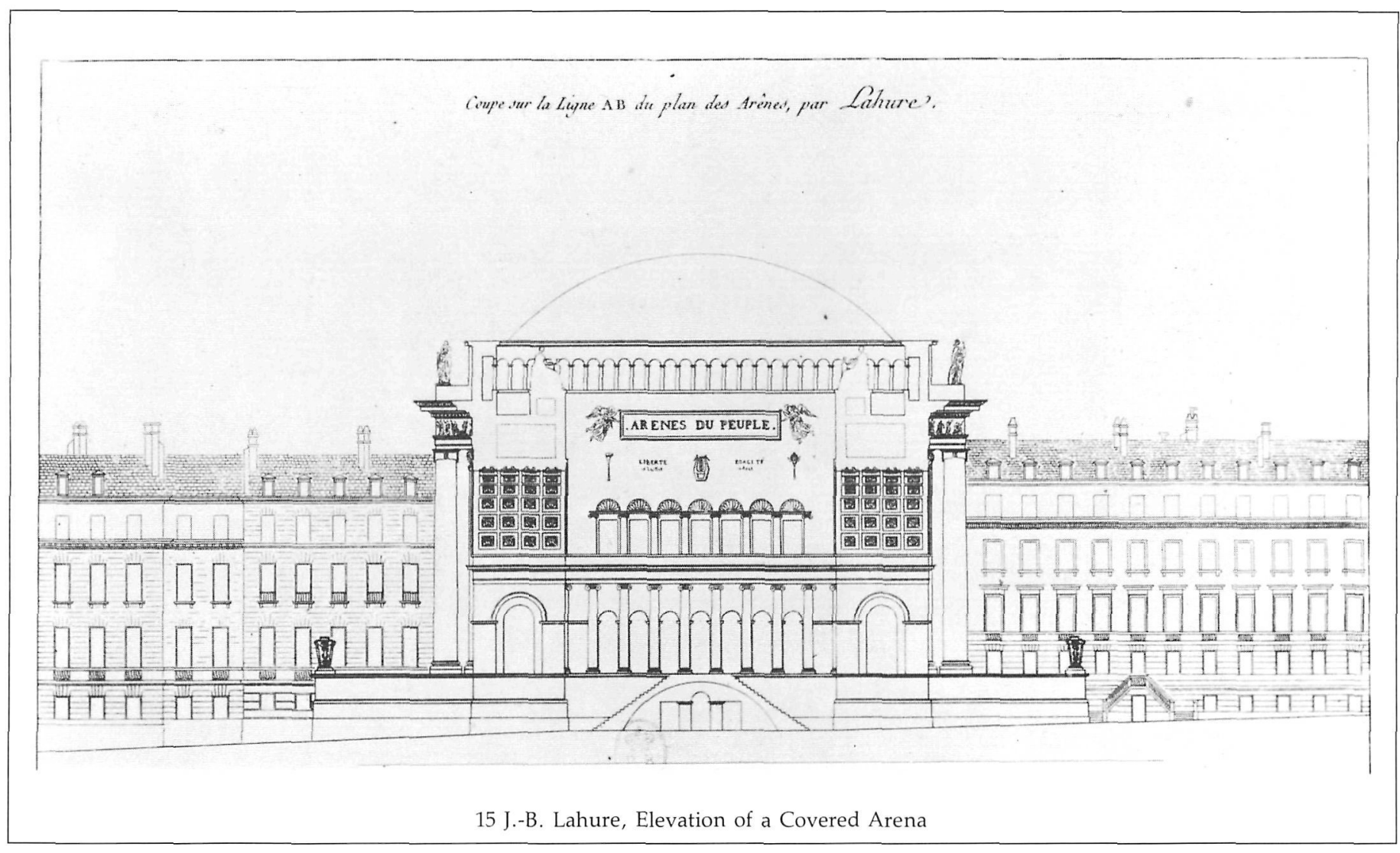

15 J.-B. Lahure, Elevation of a Covered Arena 


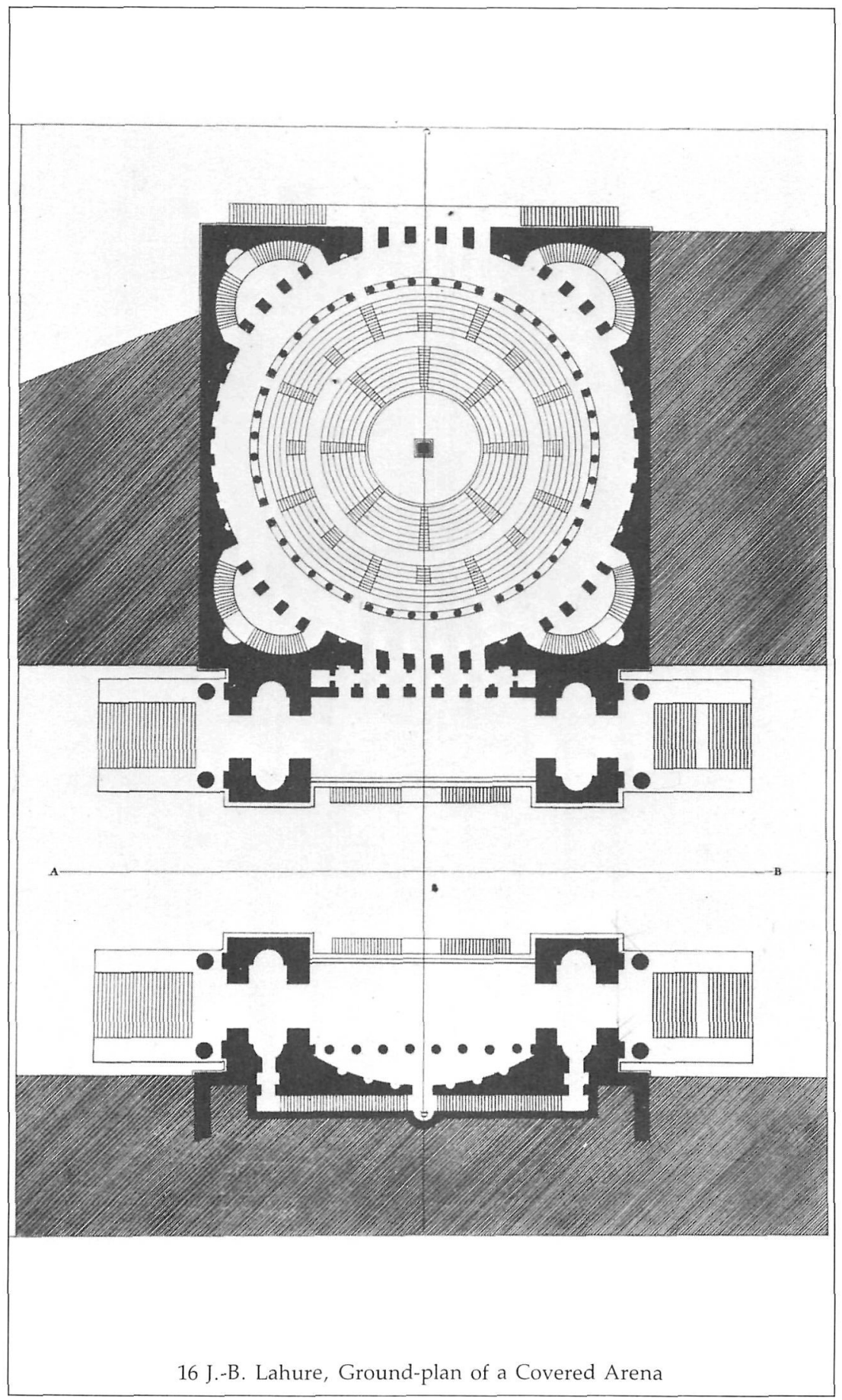




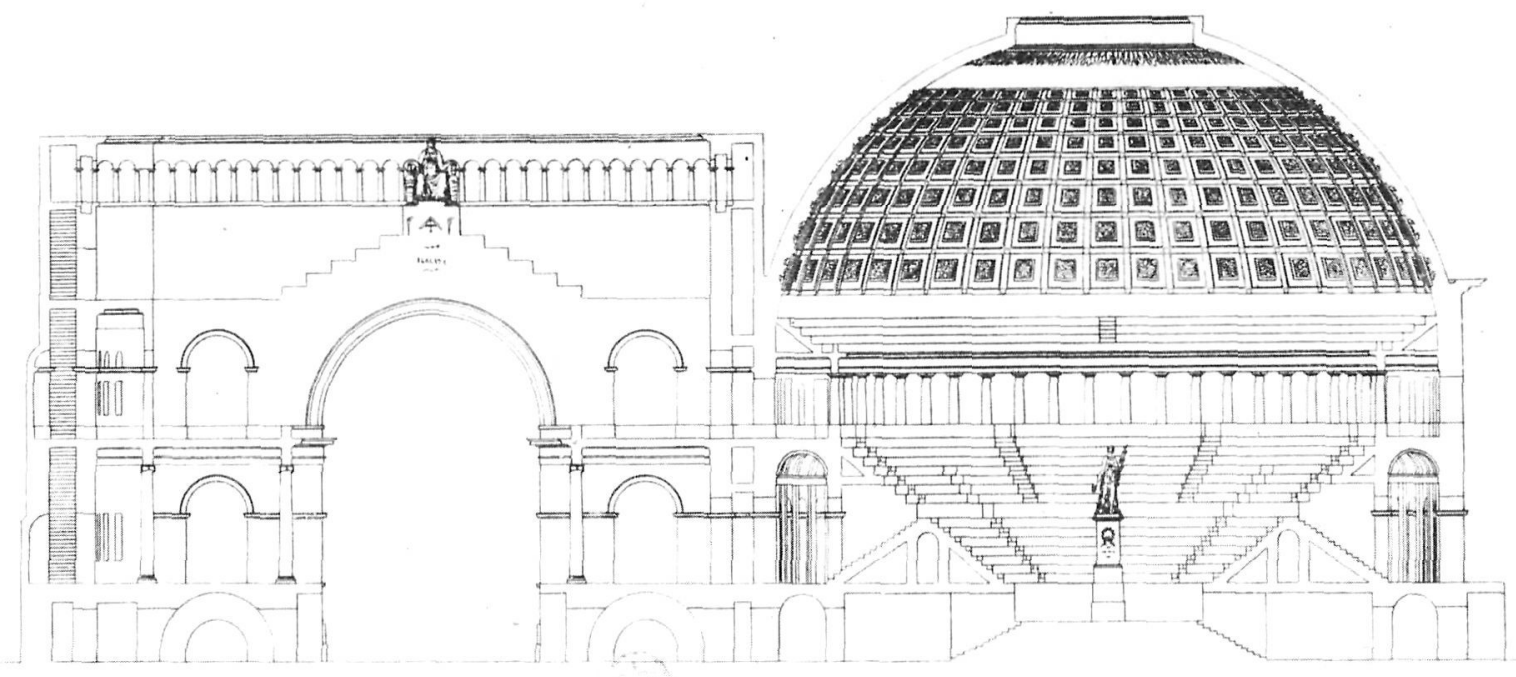

Cimpre sur la Ligne C D

17 J.-B. Lahure, Cross-section of a Covered Arena 

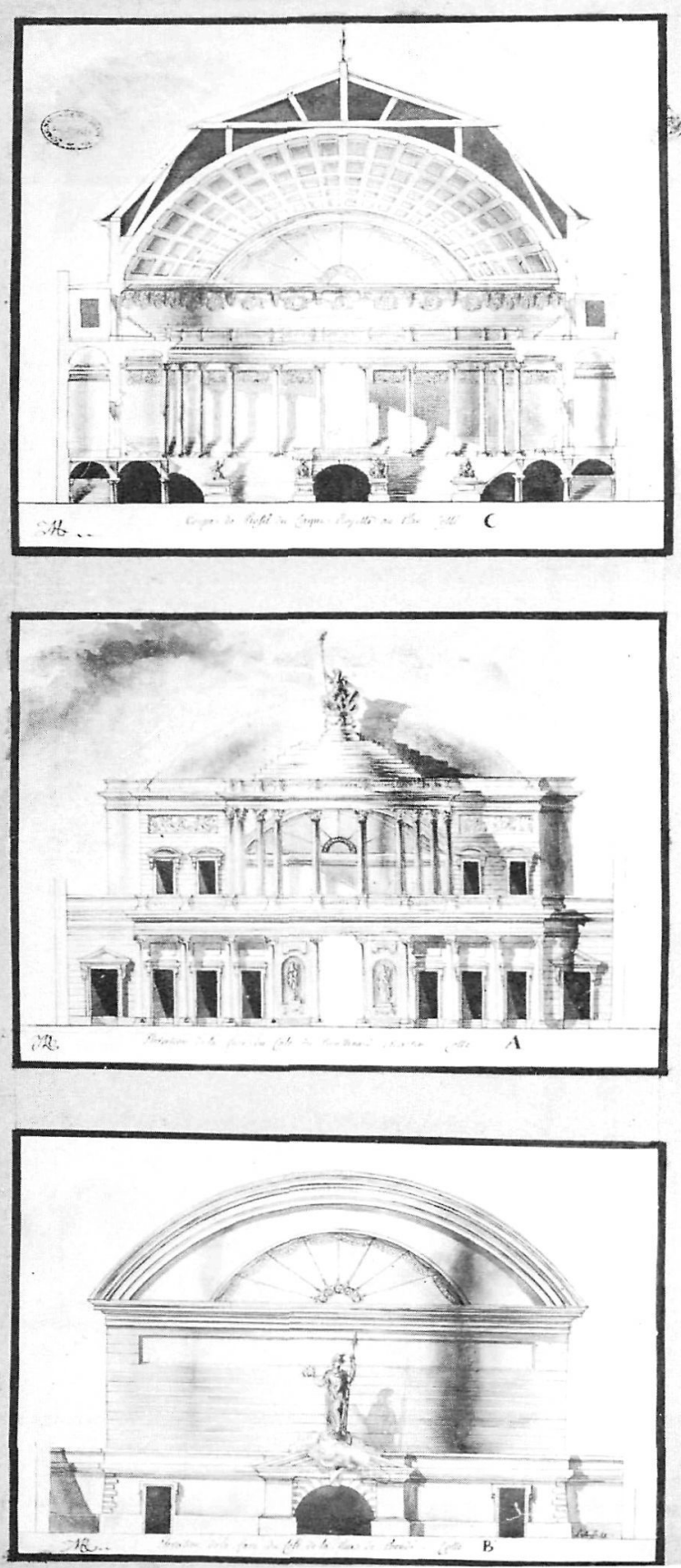

18 Riffault, Cross-section, front view, and rear-view of a Covered Arena 


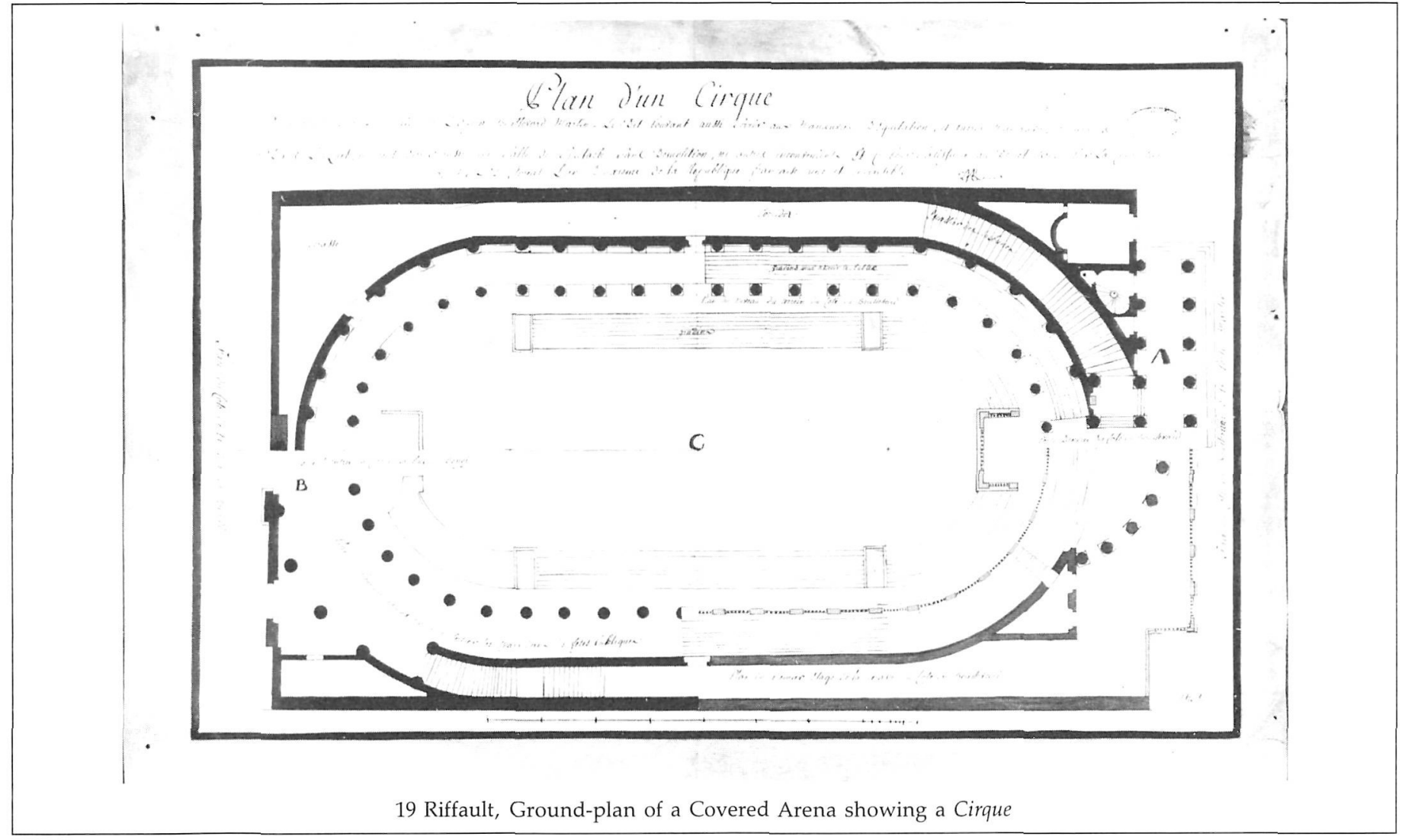




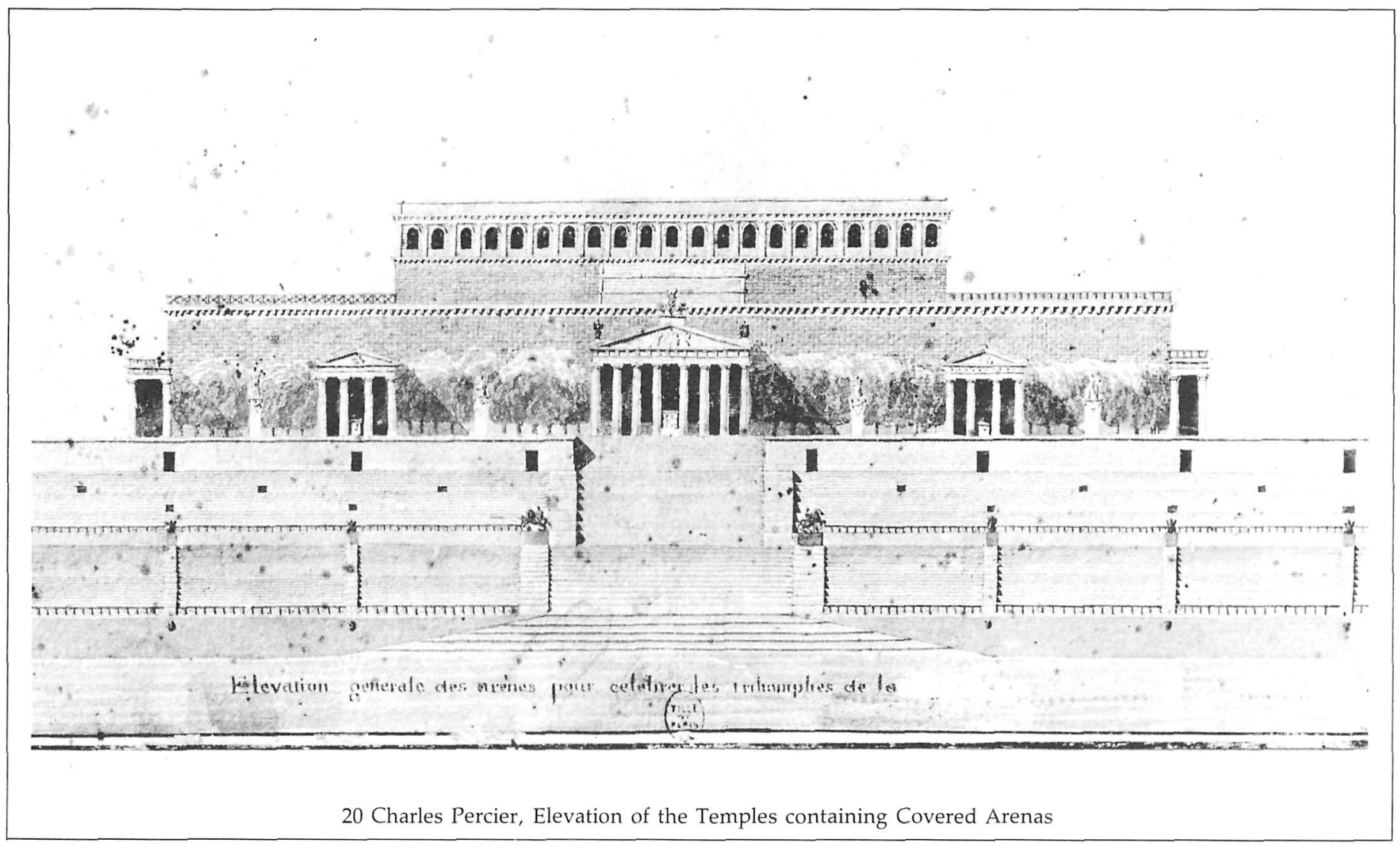




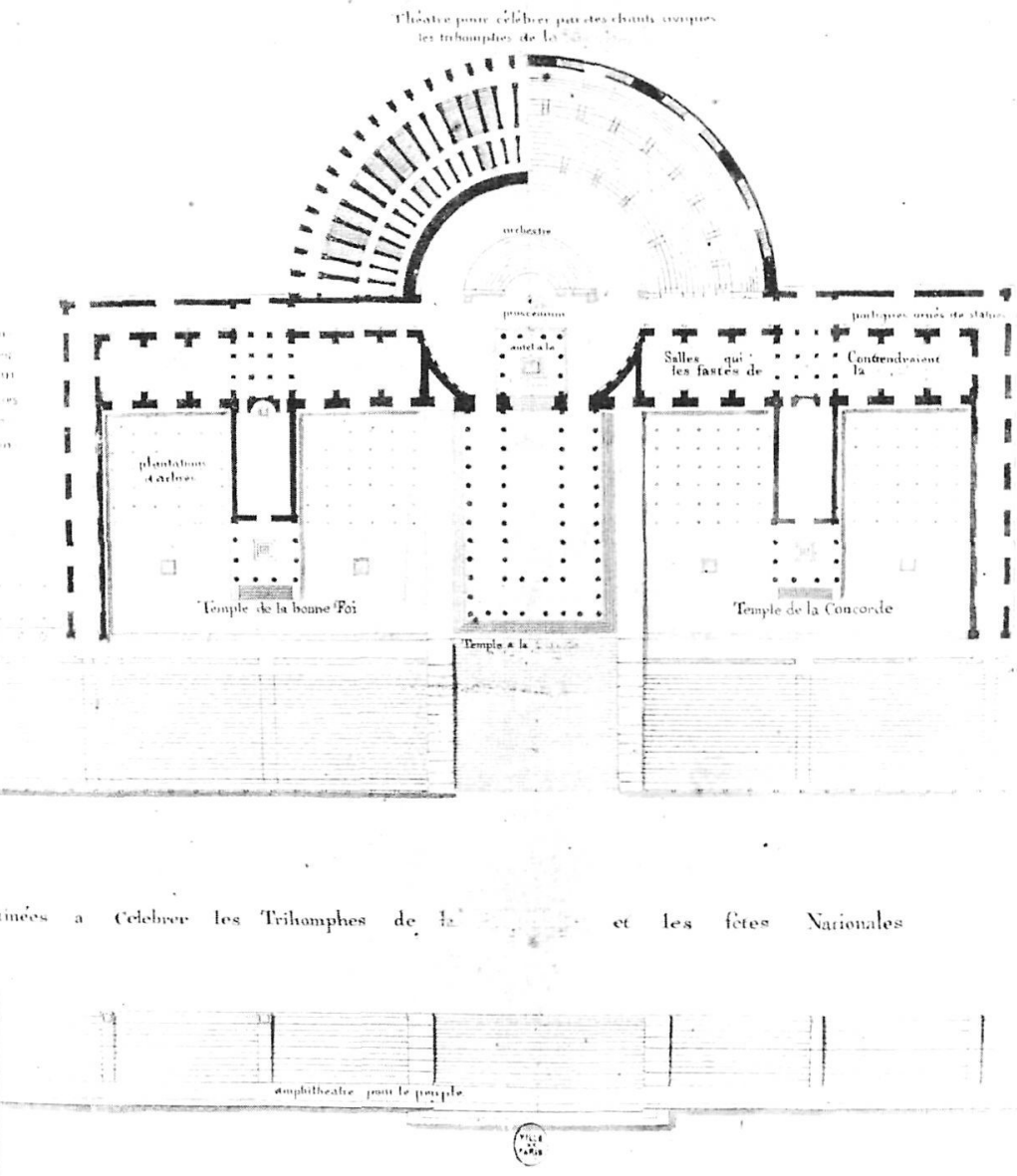

21 Charles Percier, Ground-plan of the three Temples 


\section{Elevation vue de face}

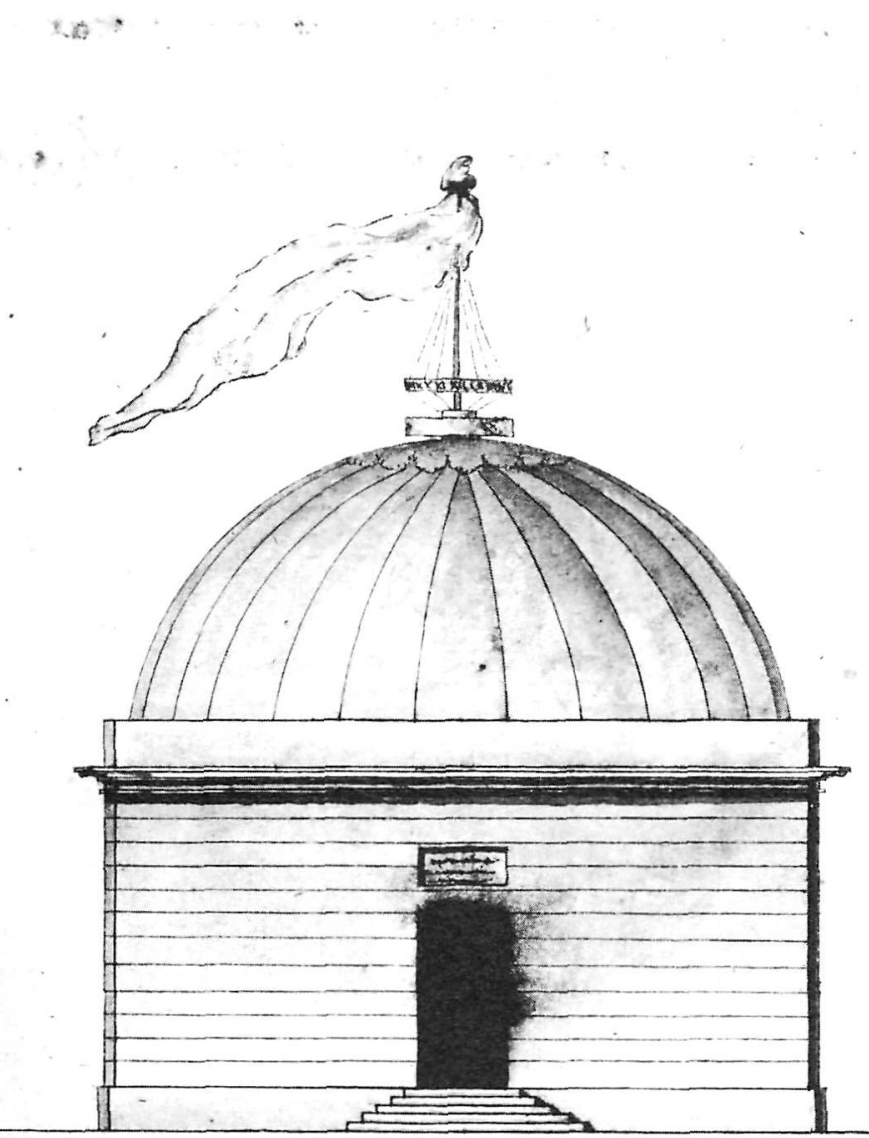

Echelle สe

22 Belu, Elevation of a Temple Décadaire for a provincial town 


\section{Plan}

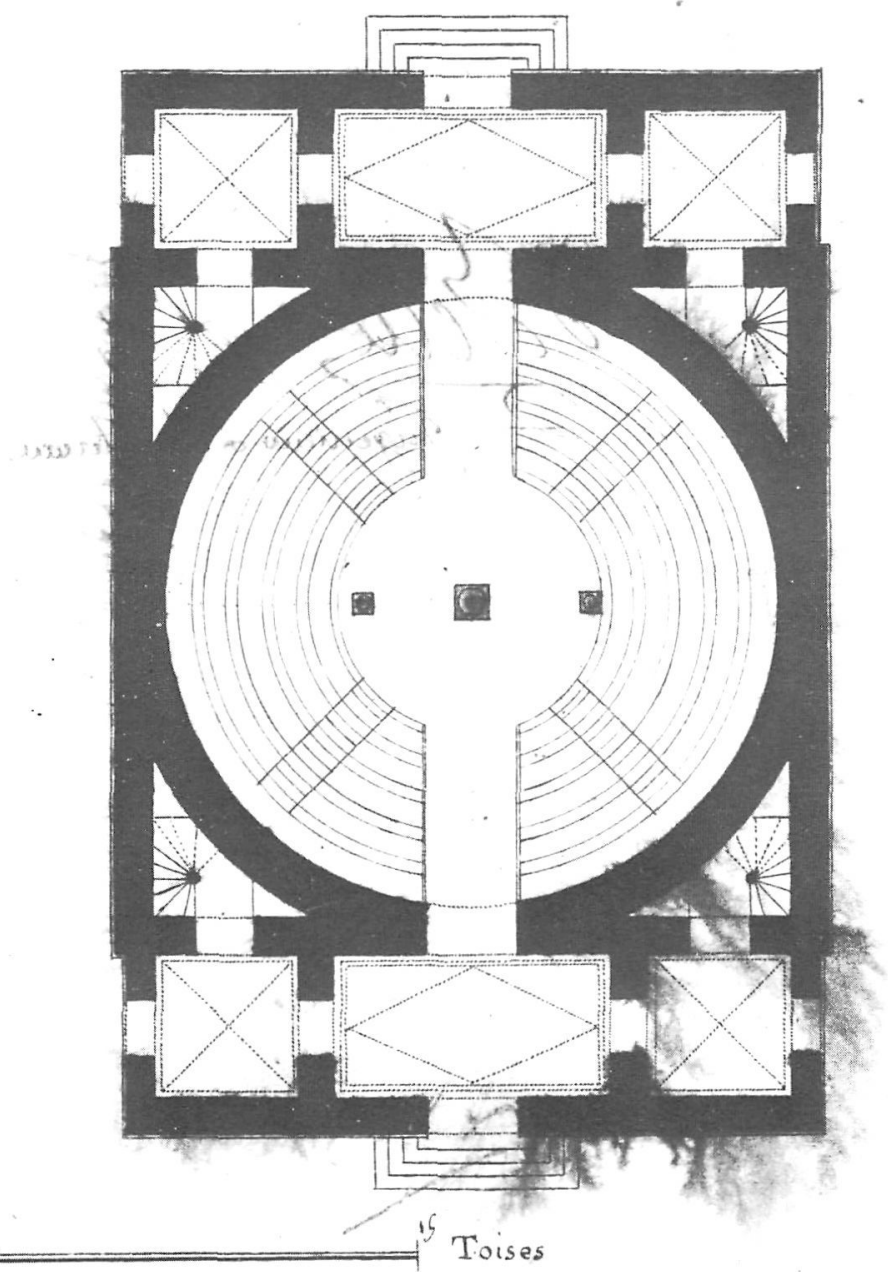

23 Belu, Ground-plan of a Temple Décadaire for a provincial town 


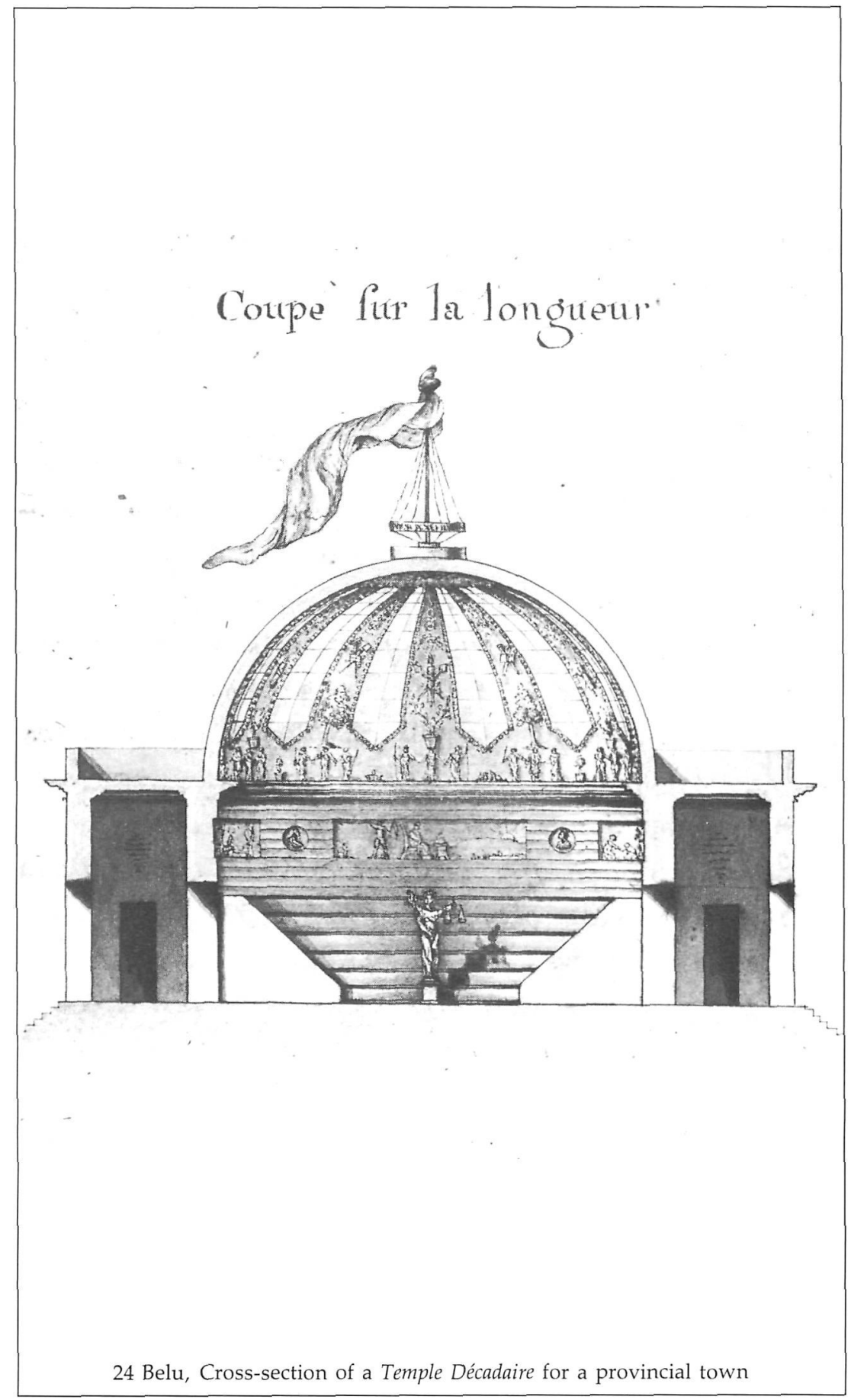




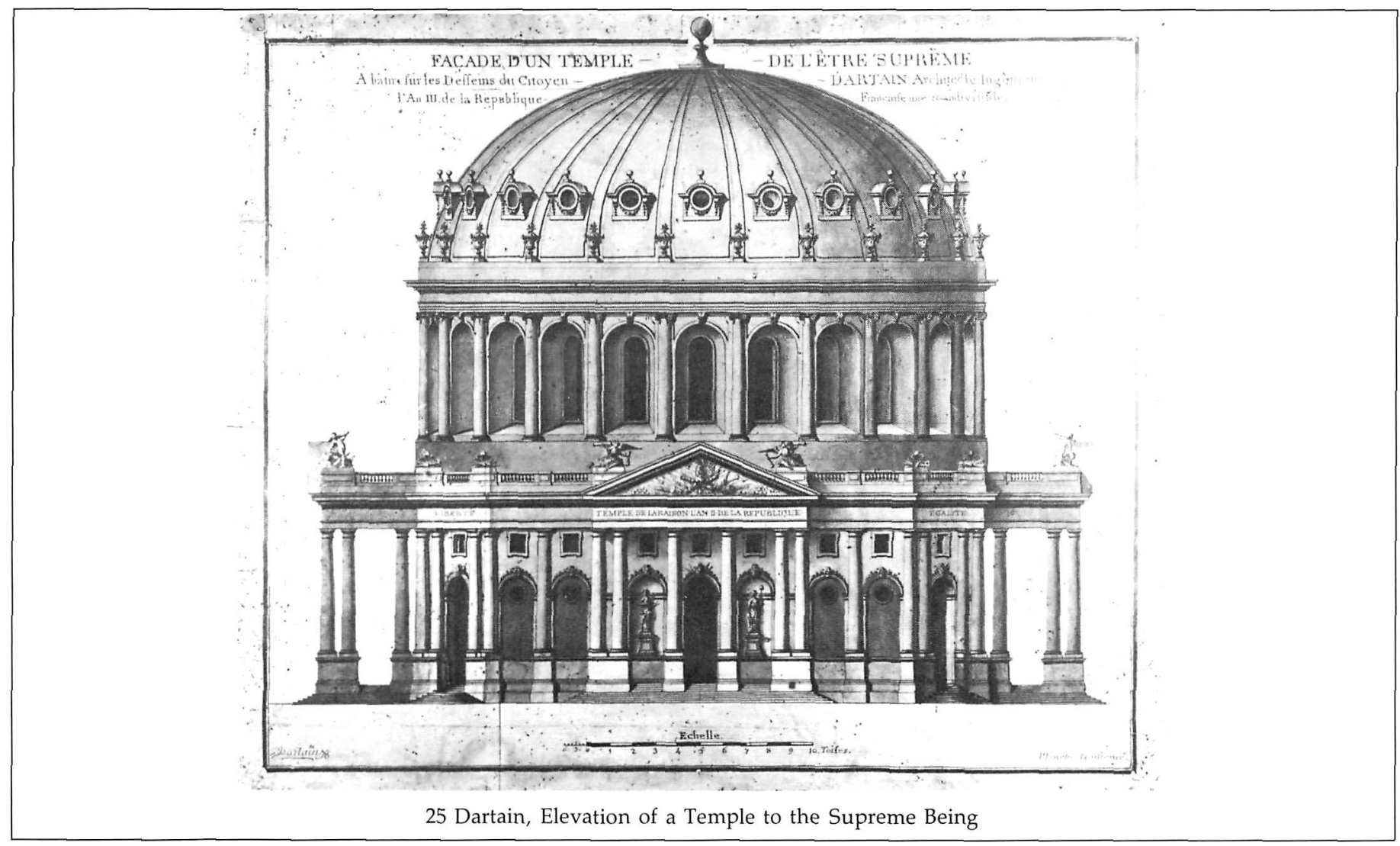




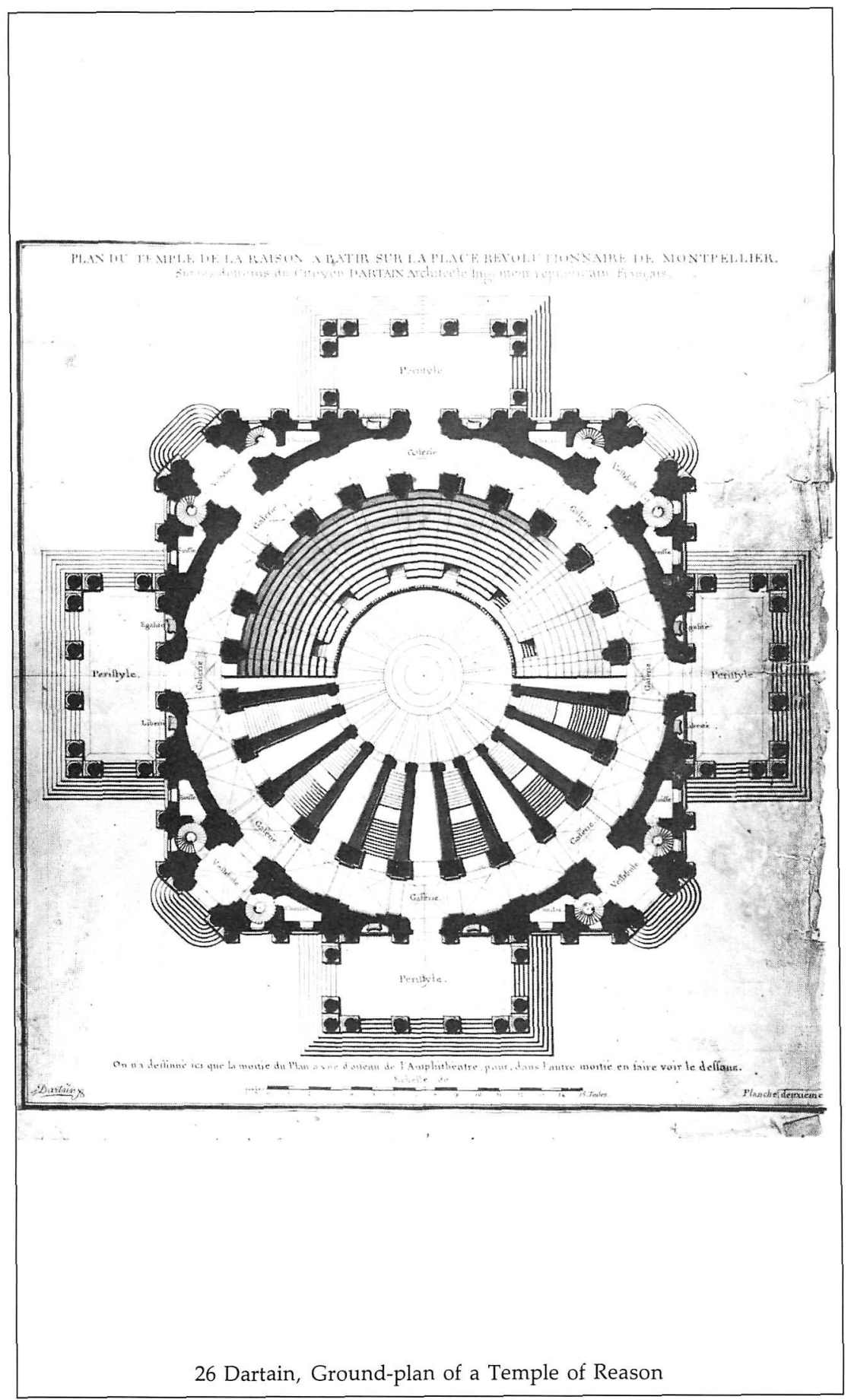



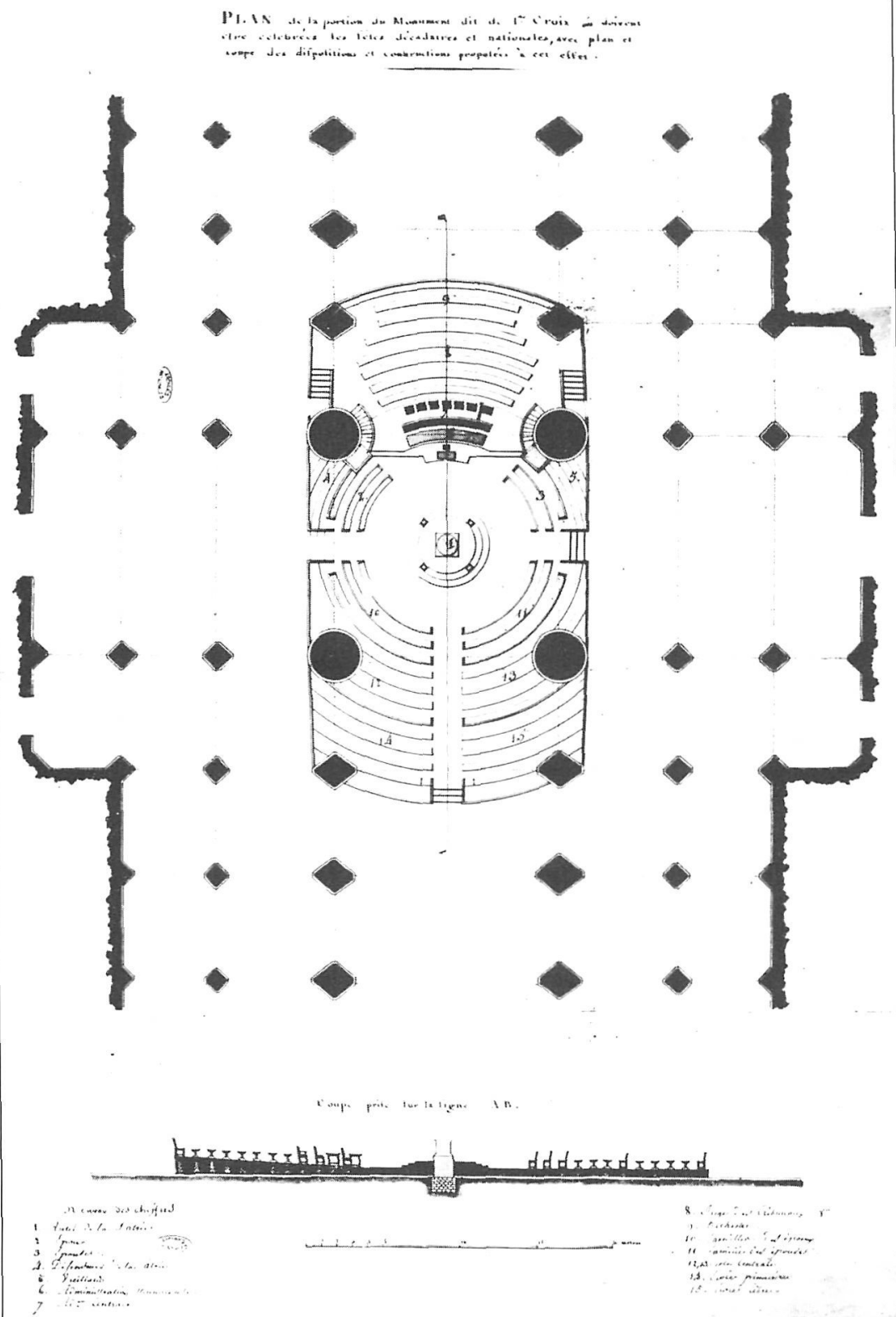

27 Anon., Plan to create amphitheatre in the Cathedral of Orléans 


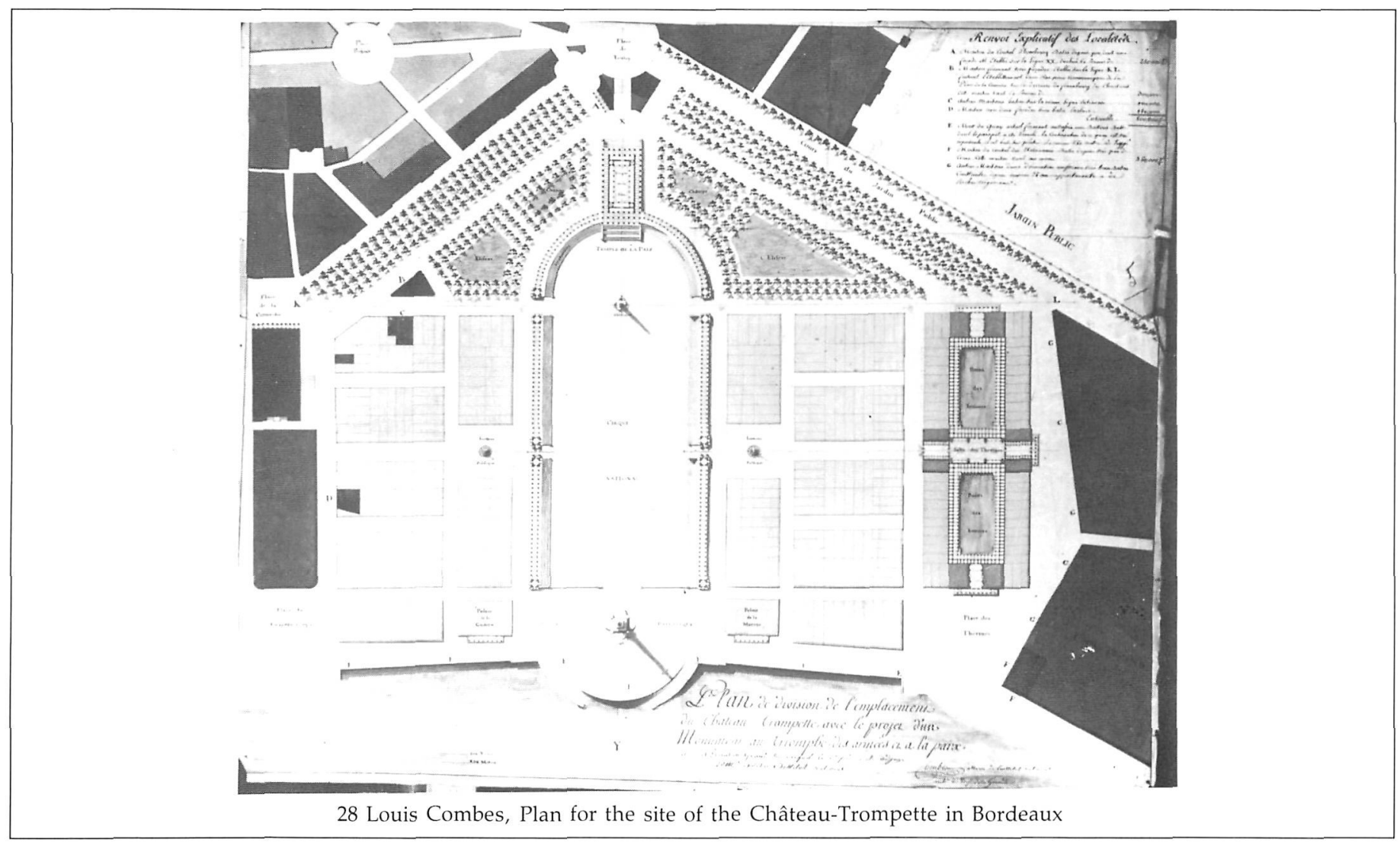




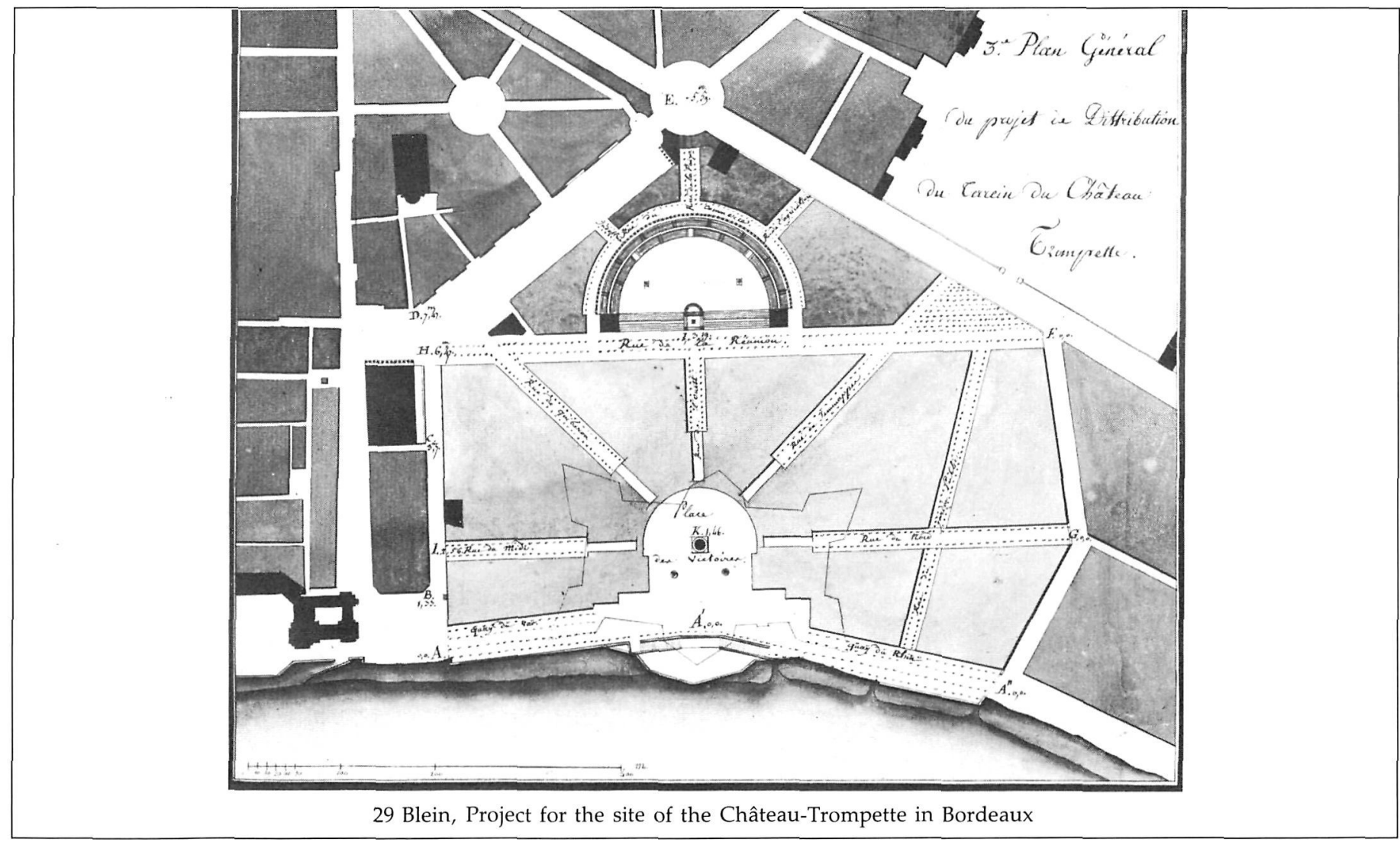




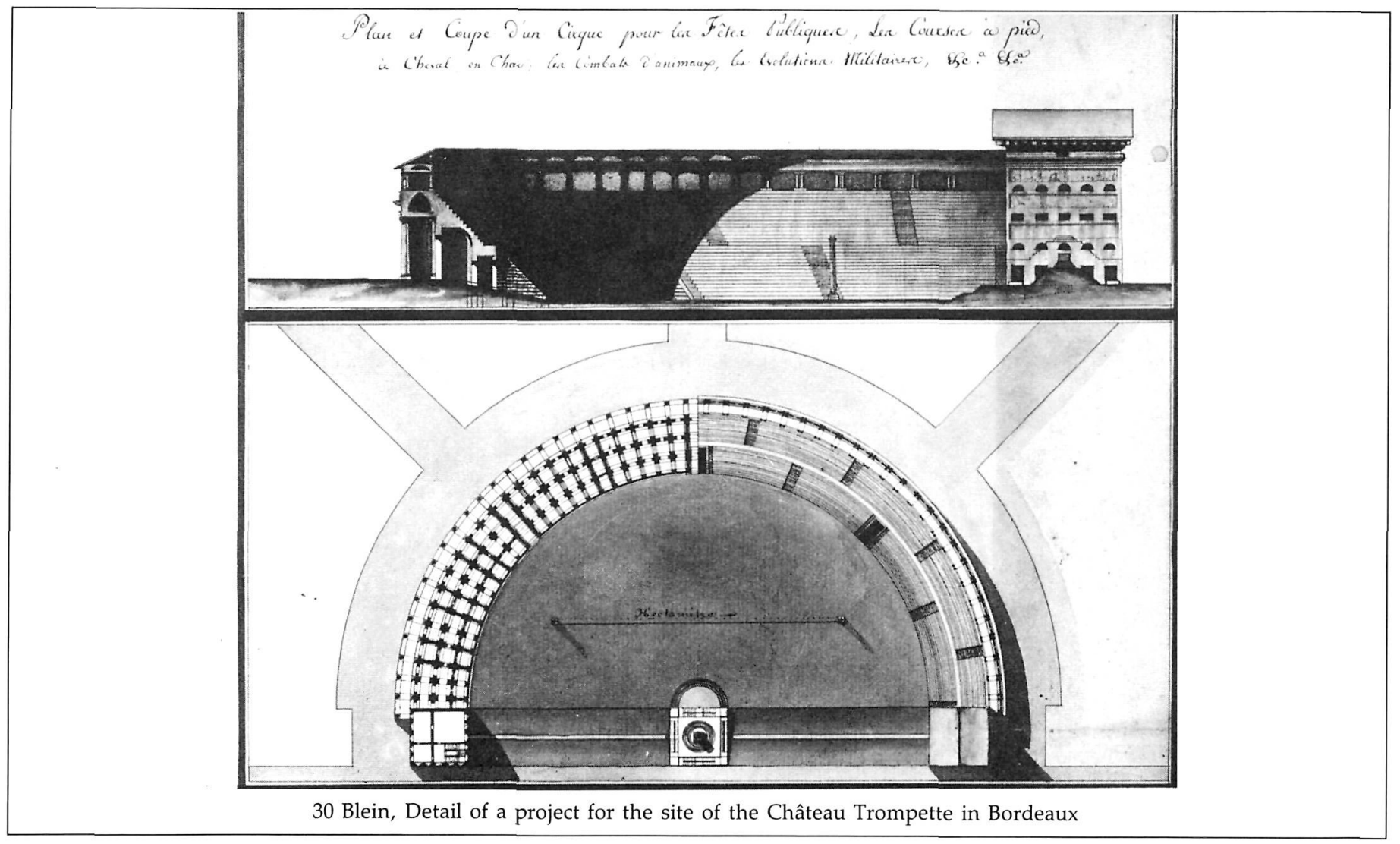

